ISSN (print): 1698-6180. ISSN (online): 1886-7995

www.ucm.es/info/estratig/journal.htm

Journal of Iberian Geology 36 (2) 2010: 145-164

doi:10.5209/rev_JIGE.2010.v36.n2.3

\title{
Early and "Middle" Cretaceous Iguanodonts in Time and Space
}

\author{
Iguanodontes del Cretácico temprano y "medio" en el tiempo y \\ en el espacio
}

\author{
K. Carpenter ${ }^{1 *}$, Y. Ishida ${ }^{2}$ \\ ${ }^{1}$ USU-CEU Prehistoric Museum, 155 East Main Street, Price, UT 84501, USA \\ ${ }^{2}$ Department of Natural History Sciences, Hokkaido University, Sapporo 06-0810, Japan \\ *Ken.Carpenter@ceu.edu
}

Received: 28/11/09 / Accepted: 30/06/10

\begin{abstract}
Recent discoveries of diverse iguanodonts throughout the Cedar Mountain Formation (Utah, USA) have led us to assess the global diversity of Early Cretaceous iguanodonts. The record in England is more diverse than previously recognized due to Iguanodon being a wastebasket genus throughout the Twentieth Century. Several new taxa, previously recognized as generically distinct by Harry Grovier Seeley, are named. The spatial and temporal distributions of iguanodonts are plotted on global maps as a key to understanding the origin of the Cedar Mountain Formation iguanodonts.
\end{abstract}

Keywords: Early Cretaceous, Iguanodonts, Dinosauria

\section{Resumen}

Los recientes descubrimientos de diversos iguanodontes en la Formación Cedar Mountain (Utah, EE.UU.) nos han llevado a valorar la diversidad global de los iguanodontes del Cretácico temprano. El registro en Inglaterra es más diverso de lo que previamente se ha reconocido, debido a que Iguanodon ha sido tratado como un género "cajón de sastre" a lo largo de todo el siglo XX. Varios de los nuevos taxones, previamente reconocidos como genéricamente distintos por Harry Seeley Grovier, se denominan. La distribución espacial y temporal de Iguanodontia se superponen sobre mapas globales como una clave para comprender el origen de los iguanodontes de la Formación Cedar Mountain.

Palabras clave: Cretácico Inferior, Iguanodontes, Dinosauria 


\section{Introduction}

Fieldwork lead by the Denver Museum of Nature \& Science in the Lower Cretaceous Cedar Mountain Formation of eastern Utah, USA, has produced several taxonomically distinct iguanodont (sensu Butler et al. 2008) specimens at different stratigraphic levels. The Cedar Mountain Formation (Valangian? - lower Cenomanian; Cifelli et al., 1997; Sames et al., 2008) has produced a rich and diverse dinosaur fauna that records the transition from a European-North American fauna to a Asian-North American fauna (Kirkland et al.,1997; Carpenter et al. 2002; Carpenter, 2006; Kirkland and Madsen 2007). The ornithopods of the Cedar Mountain Formation include five named taxa, Tenontosaurus sp., Eolambia caroljonesa, Planicoxa venenica, Cedrorestes crichtoni, and the nomen dubium Iguanodon ottingeri (Galton and Jensen, 1979; Kirkland et al., 1997; Kirkland 1998; Dicroce and Carpenter 2001; Gilpin et al., 2006). This diversity will increase as several new taxa are described from the Yellow Cat, Poison Strip, Ruby Ranch, and Mussentuchit members (Kirkland and Madsen 2007; Poole 2008; Ishida, 2009). This increase in diversity fulfills the prediction of Galton and Jensen (1979) that the poor representation of Lower Cretaceous ornithopods in North America at the time of their writing reflected inadequate collecting from strata of appropriate age.

To understand better these Cedar Mountain specimens in a global context of the Early Cretaceous iguanodonts, a review was undertaken by us as a house-cleaning preliminary to detailed description of the new specimens. The results shared below to facilitate research by our colleagues. Localities for specimens are given relative to the nearest town because locality names are not always geographically informative. The taxa are plotted on shoreline maps (Fig. 1), which are overly simplified in that they imply punctuated transgressions and regressions between stages, rather than constant changes that high resolution stratigraphy reveals (e.g., Baraboshkin, 1999; Baraboshkin et al., 2003; Alonso et al., 1993). Furthermore, as previously shown by Carpenter and Wilson (2008) with Camptosaurus, the ilium of ankylopollexians can be used to separate species once the range of variation is understood. This concept is developed further with this study as shown in Fig. 2 and discussed below. As a result, several new taxa are identified and names proposed. Terminology used in this study is illustrated in Fig. 3. The term "lateral process" is used instead of "supra-acetabular process" because the prominent projecting structure (either a flange or localized thickening) is located on the postacetabular process, rather than dorsal to the acetabulum. The process may or may not be present on the lateral iliac crest, the ridge below and parallel to the dorsal surface of the ilium.

Abbreviations: AMNH - American Museum of Natural History, New York, New York, USA. BMNH R - British Museum of Natural History Fossil Reptile Collection (=Natural History Museum of London), London, UK. CEUM - College of Eastern Utah Museum, Price, Utah, USA. DMNH - Denver Museum of Natural History (now the Denver Museum of Nature and Science), Denver, Colorado USA. FPDM - Fukui Prefecture Dinosaur Museum, Fukui, JP. FWMSH - Fort Worth Museum of Science and History, Fort Worth, Texas, USA. IRSNB Royal Belgian Institute of Natural Sciences, Bruxelles, BE. IVPP - Institute of Vertebrate Paleontology and Paleoanthropology, Beijing, CN. MNHN - National Museum of Niger, Niamey, NE. OMNH - Oklahoma Museum of Natural History, Norman, Oklahoma, USA; PIN - Paleontological Institute of the Russian Academy of Sciences, Moscow, RU. PU - Princeton University Museum, Princeton, New Jersey, USA. QM - Queensland Museum, Brisbane, AU. USNM - United States National Museum (now the National Museum of Natural History), Washington D.C., USA.

\section{Systematic Paleontology}

\section{Dinosauria Owen 1842}

Ornithischia Seeley, 1888

Ornithopoda Marsh, 1881

Iguanodontia Dollo, 1888 (sensu Butler et al., 2008)

\section{Altirhinus kurzanovi, Norman 1998.}

Locality: near Choyr, Mongolia.

Horizon: Khuren Dukh Formation (= Shinekhudag Formation as used by Hicks et al., 1999).

Age: middle - late Albian (Hicks et al., 1999; Ito et al., 2006; Nichols, et al., 2006).

Comments: The ilium (Fig. 2.1) is characterized by a deep body, short, tapering, rounded postacetabular process with a prominent postacetabular notch. The preacetabular process is sharply angled ventrally, but there is still a wide preacetabular notch. A prominent triangular lateral process is located along the lateral iliac crest. The ischial peduncle lacks the lateral expansion onto the lateral surface of the ilium seen in more derived iguanodonts.

\section{Cedrorestes crichtoni Gilpin, DiCroce and Carpenter 2006}

Locality: north of Moab, Utah, USA. 

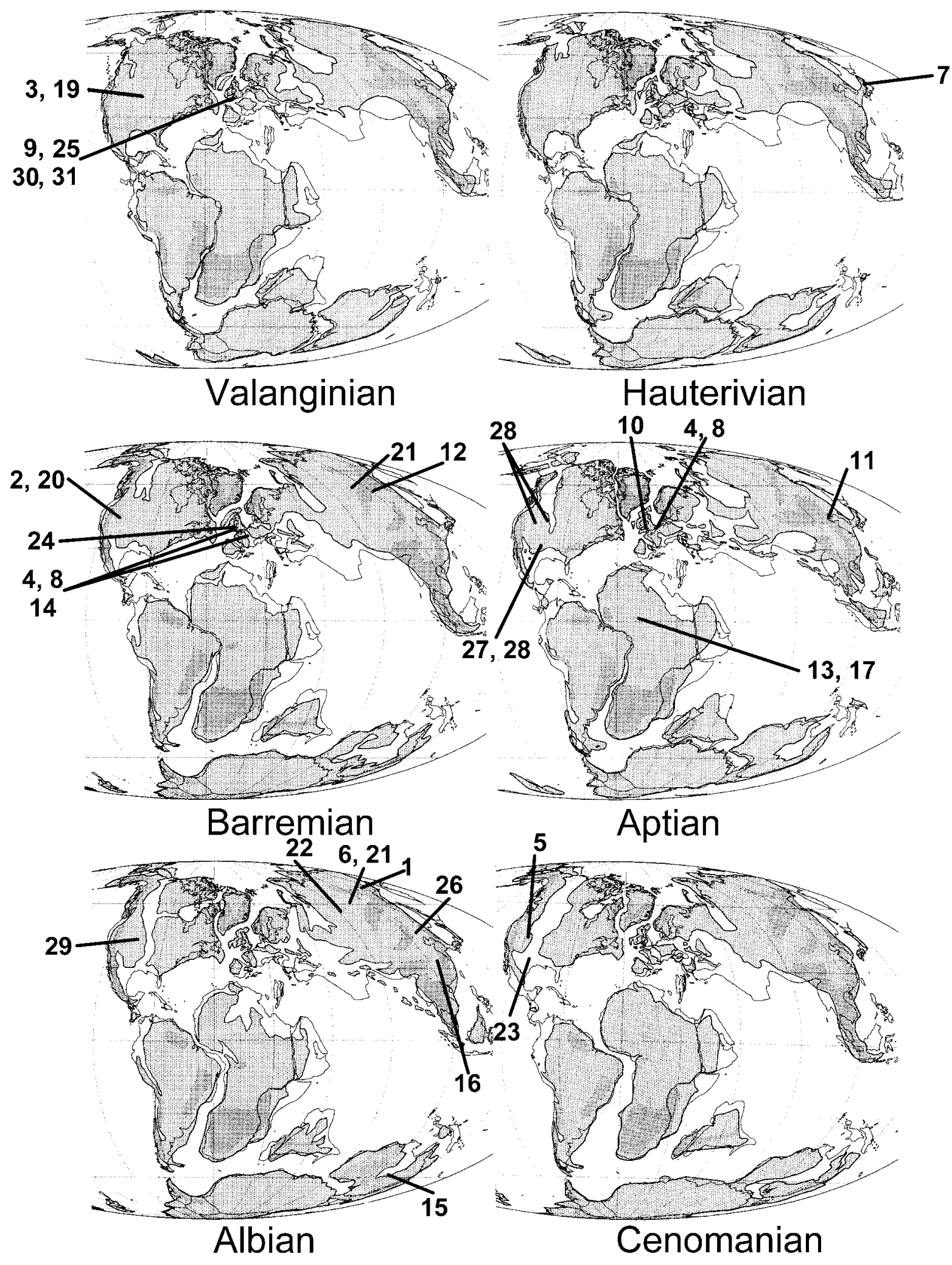

Fig. 1.- Paleogeographic maps for the Early and "Middle" Cretaceous showing coastlines. Base map based on Smith et al. (1994), and modified from Blakey (2009), with additional modifications of the Peri-Tethys from Baraboshkin et al. (2003), and Japan from Maruyama et al. (1997).

Fig. 1.- Mapas paleogeográficos del Cretácico temprano y "medio" mostrando las líneas de costa. Mapa basado en Smith et al. (1994), y modificado por Blakey (2009), con modificaciones adicionales del Peri-Tethys según Baraboshkin et al. (2003), y de Japón según Maruyama et al. (1997). 
Horizon: near top of Yellow Cat Member, Cedar Mountain Formation.

Age: late Barremian (Ludvigson et al., 2009 ; Zigler et al., 2009).

Comments: The holotype ilium (Fig. 2.2) retains the deep profile seen in basal ankylopollexians (e.g., Camptosaurus), but has a prominent flange-like lateral process considered an autapomorphy of hadrosaurids (Sereno 1999, supplemental material). Such a flange is absent in the hadrosauroid Equijubus (see Fig. 2), which also retains a deep ilium, suggesting that Cedrorestes is more derived than Gilpin et al. (2006) originally suggested. The preacetabular process is short, being about $25 \%$ of the ilium length. The ischial peduncle is slightly expanded laterally onto the postacetabular process. The postacetabular notch is broad and shallow.

\section{Dakotadon lakotaensis (Weishampel and Bjork 1989)}

Locality: north of Sturgis, South Dakota, USA.

Horizon: Chilson Member, Lakota Formation.

Age: Valanginian (Sohn, 1979; Dahlstrom and Fox, 1995; Somes and Cifelli in press).

Comment: Brill and Carpenter (2006) provided the first accurate image of the skull previously called Iguanodon lakotaensis by Weishampel and Bjork (1989). They noted that the skull differed significantly from Iguanodon and recommended that a new genus be established for it, which was done by Paul (2006). No ilium is known.

\section{Dollodon seelyi (Hulke 1882a) \\ = Iguanodon mantelli von Meyer 1832 (in part) \\ =Iguanodon seelyi Hulke 1882a \\ = Iguanodon atherfieldensis Norman 1986 \\ =Dollodon bampingi Paul 2008}

Locality: Bernissart, Belgium; Brook, Isle of Wight, England.

Horizon: Sainte-Barbe Clays; Wessex Formation.

Age: Barremian (Martill, personal communication, 2010).

Comments: Paul (2008) erected Dollodon bampingi for a specimen previously referred to Iguanodon atherfieldensis by Norman (1986) and to Iguanodon mantelli by Dollo (1882). The ilium of Dollodon bampingi is practically indistinguishable from that of Iguanodon seelyi Hulke $1882 \mathrm{a}$, and therefore the species seelyi has priority over bampingi. The distinctiveness of Dollodon from Iguanodon was noted previously by Seeley (1887a) based on the specimen referred to I. seelyi. The ilium of Dollodon is characterized by a very long, tapering postacetabular process in which the ventral margin slopes dorsally (Fig. 2.4a, b). The preacetabular process is long (almost half the ilium length), parallel-sided and angled anteroventrally. The lateral iliac crest is short, and the ischial peduncle expanded onto the lateral surface.

\section{Eolambia caroljonesa Kirkland $1998 b$}

Locality: eastern Utah, USA.

Horizon: Mussentuchit Member, Cedar Mountain Formation.

Age: early Cenomanian (Garrison et al., 2007).

Comments: Known from several localities in the Mussentuchit. The ilium (Fig. 2.5) has a deep body, triangular postacetabular process with a lateral iliac crest, but no lateral process. The preacetabular process angles sharply down. The ischial peduncle is primitive, having to lateral expansion onto the lateral surface.

\section{Equijubus normani You et al., 2003 a}

Locality: near Gongpoquan, Gansu Province, China. Horizon: Middle Grey Unit of Xinminbao Group.

Age: Albian (Tang et al., 2001).

Comments: The ilium (not previously described) most closely resembles that of "Iguanodon mantelli" in being deep, having a highly arched dorsal margin, short postacetabular process, and knob-like lateral process. It differs however in the much deeper body relatively to its length (Fig. 2.6). The ischial peduncle is ventrally offset from the postacetabular process resulting in a well-developed postacetabular notch. The peduncle is expanded onto the lateral surface of the ilium.

\section{Fukuisaurus tetoriensis Kobayashi and Azuma 1993}

Locality: near Katsuyama City, Fukui Prefecture, Japan. Horizon: Okurodani Formation (formerly Kitadani Formation - Matsukawa et al.,2003)

Age: Hauterivian (Fuijita, 2003).

Comments: This taxon is represented by considerably more material than when first described. The ilium also has not been described previously (Fig. 2.7). Superficia1ly, it resembles the ilium of Equijubus and "Iguanodon mantelli", but differs in a long, overhanging (laterally projecting) lateral iliac crest, and small, triangular expansion onto the postacetabular process.

\section{Iguanodon bernissartensis Boulenger 1881}

Locality: Bernissart, Belgium; Brook, Isle of Wight, England

Horizon: Sainte-Barbe Clays; Wessex Formation.

Age: late Barremian-earliest Aptian (Yans et al., 2005; Dejax et al., 2006; Home, 1995).

Comments: This taxon was made the type species for the nominal genus Iguanodon Mantell 1825 by the In- 

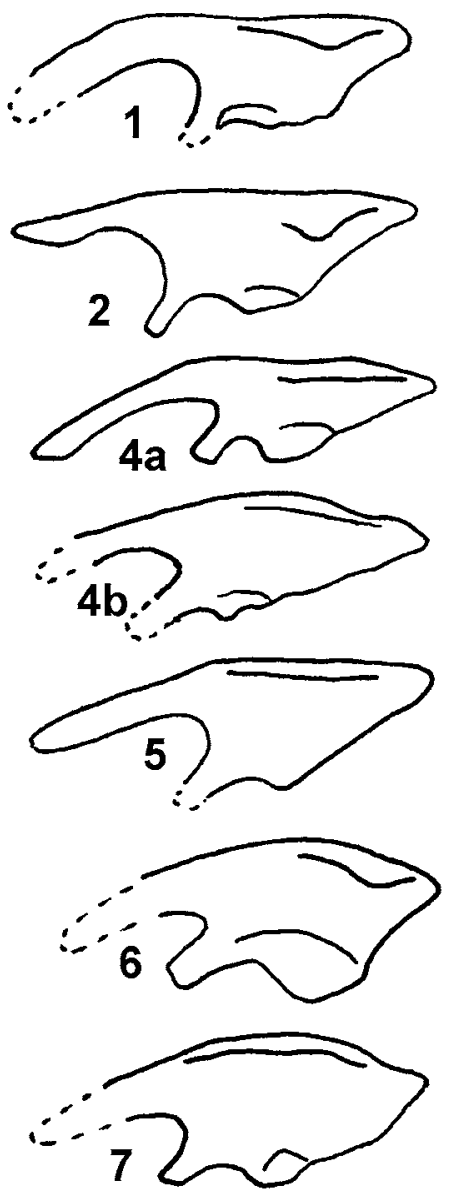
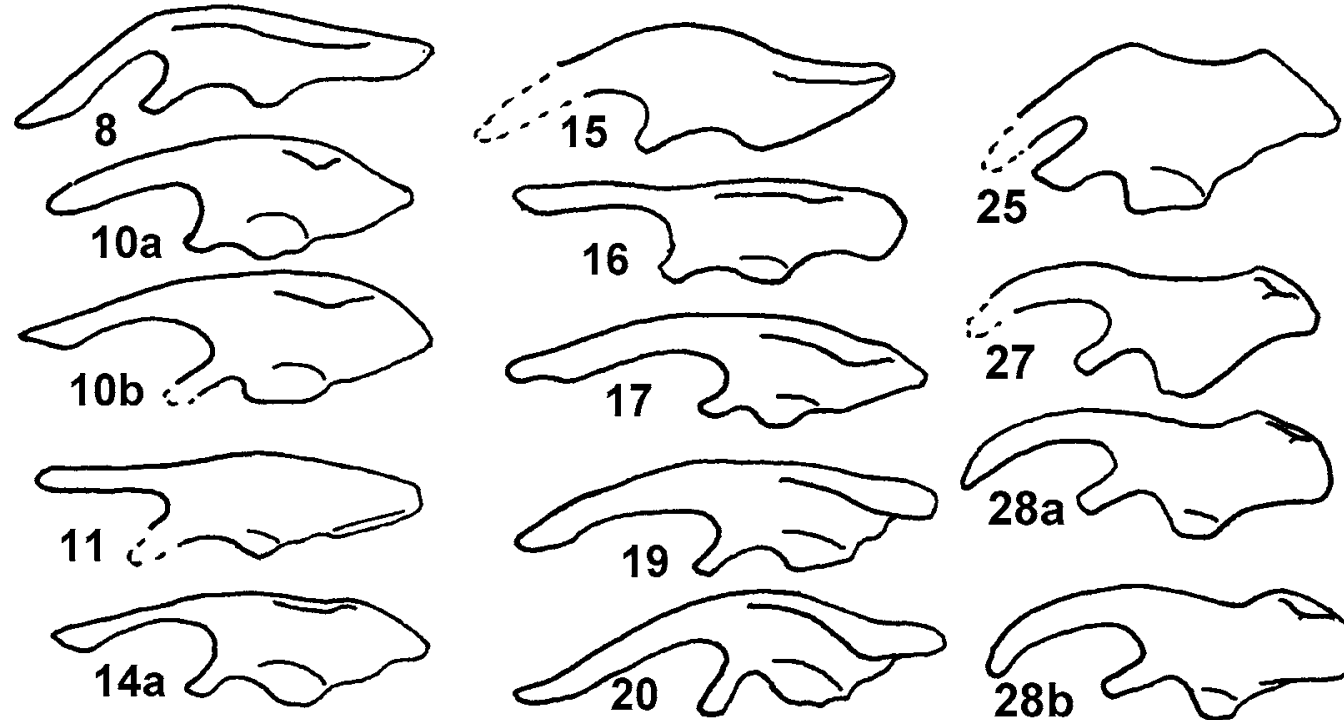

11
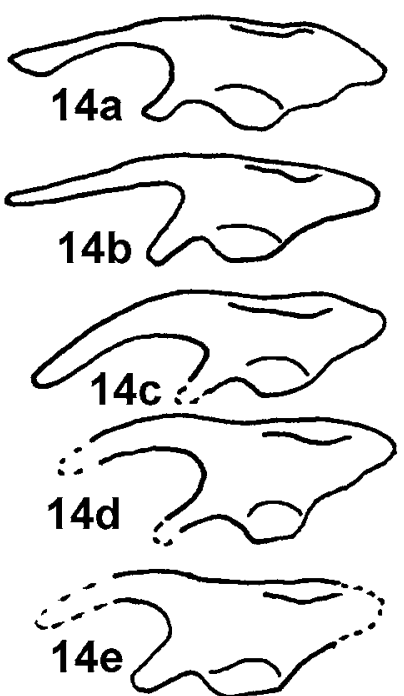
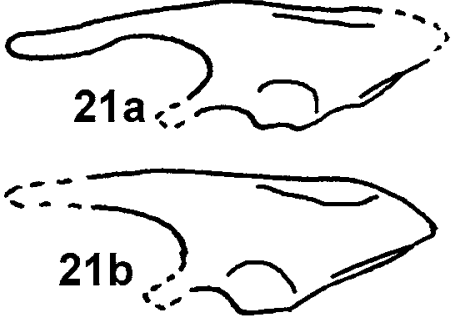

$28 \mathrm{c}$
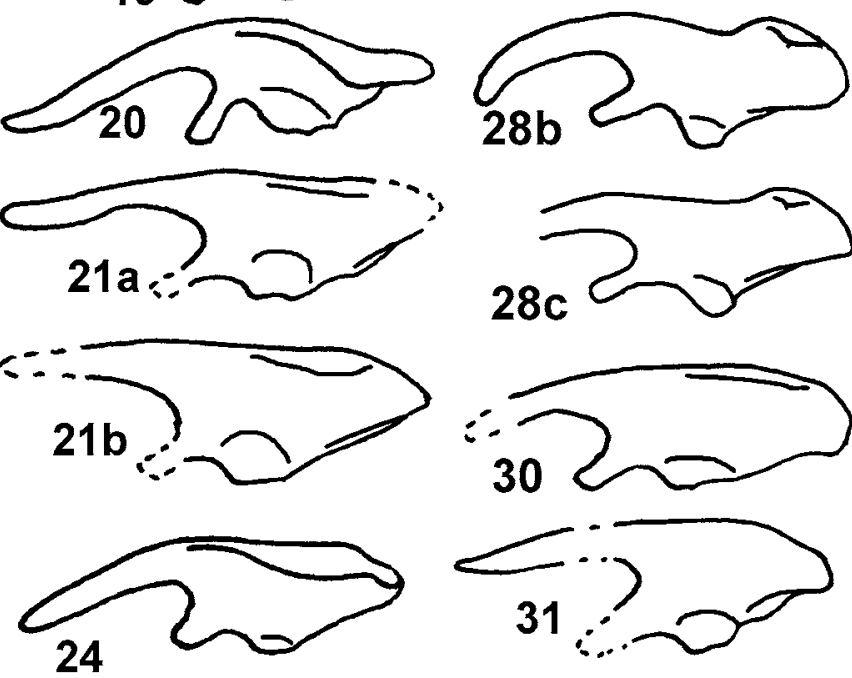

Fig. 2.- Comparison of ilia of various iguanodonts. Numbers correspond to taxa in text (not all taxa are known by ilia). From original images except where noted (some images reversed for comparison). 1 - Altirhinus kurzanov PIN (Norman 1998); 2 - Cedrorestes crichtoni DMNH 47994; 4 - Dollodon seelyi a - IRSNB 1551, b, BMNH R 28685 (Hulke 1882); 5 - Eolambia caroljonesa CEUM 14466; 6 - Equijubus normani IVPP 12534 (You et al., 2003);7 - Fukuisaurus tetoriensis FPDM mounted skeleton; 8 - Iguanodon bernissartensis IRSNB $1534 ; 10$ - “Iguanodon”" mantelli a - BMNH R 3741, b - BMNH R 9296 (Martill and Naish 2001); 11, Jinzhousaurus yangi (IVPP V12691); 14 - Mantellisaurus atherfieldensis a - BMNH R 5764, b - BMNH R11521, c - BMNH R 8649, d - BMNH R 6462, e - BMNH R 113 (Lydekker 1890 ); 15 - Muttaburrasaurus langdoni QM F6140 (Bartholomai and Molnar 1981); 16 - Nanyangosaurus zhugeii IVPP 11821; 17 - Ouranosaurus nigeriensis MNHN GDF 300 (Taquet 1976); 19 - Planicox depressus USNM 4753;20 - Planicoxa venenica DMNH 42504; 21 - Probactrosaurus gobiensis a - PIN 2232/19-1, b - PIN 12017 (Norman 2002); 23 - Proplanicoxa galtoni BMNH 8649; 25 - Sellacoxa pauli BMNH R $3788 ; 27$ - Tenontosaurus dossi FWMSH 93B2 (Winkler et al. 1997); 28 - Tenontosaurus tilletorum a - AMNH 3040, b - OMNH 10132; c - PU 16338 (specimen now at the Philadelphia Academy of Natural Sciences) ; 30 - Torilion dawsoni BMNH R 811; 31 - Wadhurstia fittoni BMNH R 1635 . No to scale, to approximately the same length for comparison.

Fig. 2.-Comparación de los ilion de varios iguanodontes. Los números corresponden a los taxones referidos en el texto (no de todos los taxones se conocen los ilion). Todas son imágenes originales, en caso contrario se menciona (algunas imágenes han sido giradas para su mejor comparación). 1 - Altirhinus kurzanov PIN (Norman 1998); 2 - Cedrorestes crichtoni DMNH 47994; 4 - Dollodon seelyi a - IRSNB 1551, b, BMNH R 28685 (Hulke 1882); 5 - Eolambia caroljonesa CEUM 14466; 6 - Equijubus normani IVPP 12534 (You et al., 2003);7 - Fukuisaurus tetoriensis FPDM esqueleto montado; 8 - Iguanodon bernissartensis IRSNB 1534; 10 - “Iguanodon” mantelli a - BMNH R 3741, b - BMNH R 9296 (Martill and Naish 2001); 11, Jinzhousaurus yangi (IVPP V12691); 14 - Mantellisaurus atherfieldensis a - BMNH R 5764, b - BMNH R11521, c - BMNH R 8649, d - BMNH R 6462, e - BMNH R 113 (Lydekker 1890); 15 - Muttaburrasaurus langdoni QM F6140 (Bartholomai and Molnar 1981); 16 - Nanyangosaurus zhugeii IVPP 11821; 17 - Ouranosaurus nigeriensis MNHN GDF 300 (Taquet 1976); 19 - Planicox depressus USNM 4753;20 - Planicoxa venenica DMNH 42504; 21 - Probactrosaurus gobiensis a - PIN 2232/19-1, b - PIN 12017 (Norman 2002); 23 - Proplanicoxa galtoni BMNH 8649; 25 - Sellacoxa pauli BMNH R 3788; 27 - Tenontosaurus dossi FWMSH 93B2 (Winkler et al. 1997); 28 - Tenontosaurus tilletorum a - AMNH 3040, b - OMNH 10132; c - PU 16338 (ejemplar deposidado actualmente en la Philadelphia Academy of Natural Sciences) ; 30 - Torilion dawsoni BMNH R 811; 31 - Wadhurstia fittoni BMNH R 1635. No están a escala, sino dispuestos con la misma dimensión para su comparación. 
ternational Commission of Zoological Nomenclature (ICZN 2000) after being petitioned by Charig and Chapman (1998). Originally one of us supported this proposal (Carpenter 1998), but now believes that this decision was in error because there is ample evidence that a type had been declared by Mantell's contemporaries operating under the "Rules for Zoological Nomenclature" for 1878: "§ 5 . When the evidence as to the original type of a genus is not perfectly clear and indisputable, then the person who first subdivides the genus may affix the original name to any portion of it at his discretion, and no later author has a right to transfer that name to any other part of the original genus." This action was definitely formalized by Hulke (1882a: 144) in a footnote: "The Iguanodon [sic] indicated by the remains in the well-known slab figured in the Foss[il] Rept[tiles] of the Cretaceous formation, $\mathrm{pl}[$ ates] xxiii, xxiv, is taken as the type of I. mantelli" (the specimen referred to is the Maidstone specimen of Mantell, see Norman, 1993). This fixation of the name to the Maidstone specimen was made because neither Mantell (1825) nor von Meyer (1832) had designated a type (or cotype) specimen. Furthermore, Owen's (1851) detailed description of the Maidstone specimen was acknowledged as the defining specimen for Iguanodon anatomy prior to the discovery of the Bernissart specimens (e.g., Owen, 1853; Leidy, 1858; Hulke, 1873a). This action by Hulke essentially formalized what had been widely accepted by the scientific community at the time (e.g., Dollo, 1882: 170) and accepted thereafter (e.g., Woodward 1885, Lydekker, 1888a: 219; Woodward and Sherborn, 1890: 241 footnote; Dollo, 1909: 101; Hooley, 1912: 444; Swinton, 1951). However, because of the ICZN (2000) ruling, nomenclature stability would be upset by altering the type species for Iguanodon. We therefore reluctantly accept $I$. bernissartensis as the type species for the genus at this time, but belief the issue needs to be re-examined.

The ilium is long and low (Fig. 2.8), with a very long postacetabular process, and long, ventrally angled preacetabular process that expands distally before tapering to the tip. The process is almost parallel to the long, slender pubic peduncle resulting in a narrow preacetabular notch. The lateral iliac crest is long, extending to the distal end of the postacetabular process and is a prominent overhang for most of its length (see Norman 1980, fig 64 for cross-sections). The dorsal and ventral edges of the postacetabular process are parallel, except distally. A prominent brevis shelf is present along the ventral margin of the postacetabular process, but this is not visible in lateral view. The ischial peduncle is broad, but is not expanded onto the lateral surface of the ilium. There is a moderately develop postacetabular notch.

\section{9. “Iguanodon” hollingtoniensis Lydekker $1889 a$}

Type Locality: Shornden, East Sussex

Horizon: Wadhurst Clay, Hastings Beds Group (Allen, 1960).

Age: lower Valanginian (Allen and Wimbledon 1991)

Comments: The syntypes (BMNH R1148, 1629, 1632, 1632a, b; Lydekker 1890a: 262-263) overall resemble Camptosaurus more than Iguanodon as first noted by Lydekker (1889a, 1890a) and more recently by Galton (2009). For example, the femur is bowed and has a pendent fourth trochanter, whereas iguanodonts typically have a straight femoral shaft and crested or ridged fourth trochanter. An exception to this generality is Planicoxa venenica, which does have a bowed femur (see DiCroce and Carpenter 2001). Lydekker (1889a, 1890a) also noted that the sacrum and ischium were also more similar to Camptosaurus. Despite these similarities, Lydekker referred the specimen to Iguanodon because of the "thumbspike", which he considered as uniquely Iguanodon. However, we now know this character is more widely distributed, occurring also in Ouranosaurus (see Taquet, 1976). The specimen is clearly not referable to Iguanodon, as also noted by Galton (2009), but at present, we are unable to identify an autapomorphy. No ilium is known.

\section{0 "Iguanodon" mantelli von Meyer 1832 \\ = Iguanodon atherfieldensis (part)}

Locality: Maidstone, Kent County;

Horizon: Hythe Formation (Lydekker 1888b), Wessex Formation

Age: Aptian (Ruffell 1992)

Comments: The issue of the currently accepted type of Iguanodon, as I. bernissartensis, does not resolve the status of the Maidstone specimen (BMNH R3741). The ilium (Fig. 2.10a) differs significantly from that of $I$. bernissartensis, as well as that of Mantellisaurus atherfieldensis to which is has often been referred (e.g., Norman 1993). It differs in that the body is very deep above the acetabulum, the dorsal margin is arched, the preacetabular process lacks a medial shelf, the postacetabular process is a short, deep triangle lacking a brevis shelf, but it does have a small, triangular, lateral process. The ischial peduncle is expanded onto the lateral surface of the ilium. Overall, the ilium is closest in appearance to that of Equijubus from the Albian of China (see above) and Fukuisaurus from the Hauterivian of Japan, yet differs in the proportionally longer postacetabular process, shallower acetabular notch, and short pubic peduncle.

It is unfortunate that type designation was overturned by the ICZN (2000) ruling because this unique taxon is without generic designation. Although a new genus 


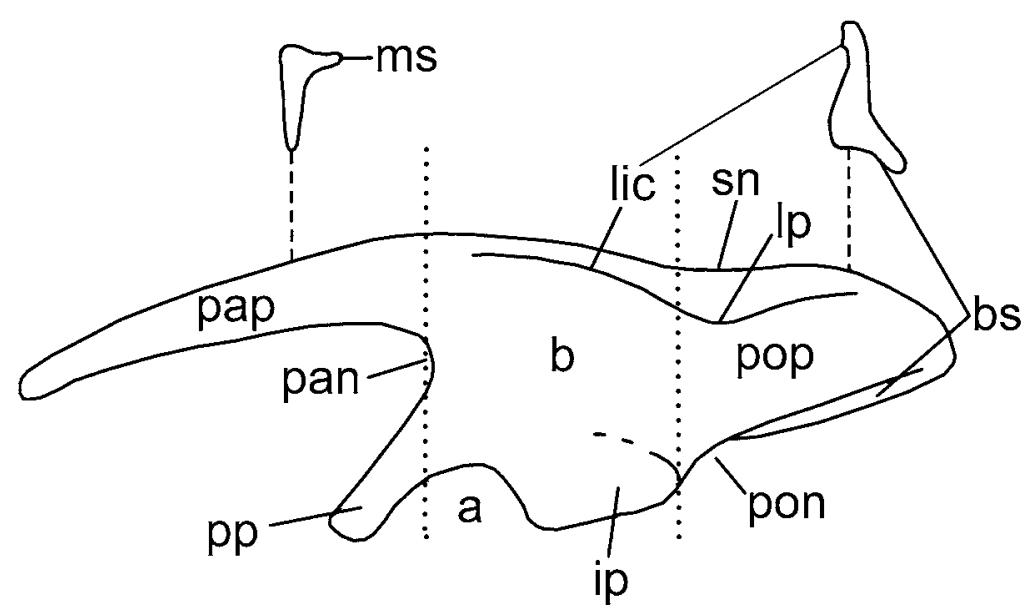

Fig. 3.-Terminology used for iguanodontid ilia: a acetabulum; b - body; bs - brevis shelf; ip - ischial peduncle; lip - lateral iliac crest; lp - lateral process; ms - medial shelf; pan - preacetabular notch; pap - preacetabular process; pon - postacetabular notch; pop - postacetabular process; $p p$ - pubic peduncle; sc - suprailiac crest; sn - suprailiac notch.

Fig. 3.- Terminología utilizada en los ilion de iguanodontes: a - acetábulo; b - cuerpo; bs - borde brevis; ip - pedúnculo isquiático; lip - cresta lateral ilíaca; $1 \mathrm{p}$ - proceso lateral; $\mathrm{ms}$ - borde medial; pan - escotadura paracetabular; pap - proceso preacetabular; pon - escotadura postacetabular; pop - proceso postacetabular; pp - pedúnculo púbico; sc - cresta suprailíaca; sn - escotadura suprailíaca. name could be proposed, this would essentially be creating a new name for a previously acknowledge holotype. It would be preferable to petition the ICZN to overturn their previous ruling, and only if that failed to propose a new generic name.

A second specimen from the Wessex Formation of the Isle of Wight (Fig. 2.20b) resembles the ilium of "I" mantelli more than it does any of the ilia of Mantellisaurus atherfieldensis to which it has been referred (Martill and Naish, 2001). It differs in a distal expansion of the preacetabular process and continuous arc of the dorsal surface over the postacetabular process.

\section{Jinzhousaurus yangi Wang and Xu 2001}

Locality: Baicaigou, Toutai, Yixian County, Liaoning, People's Republic of China.

Horizon: Dakangpu Bed (equivalent to the Dawangzhangzi Bed), Yixian Formation

Age: early Aptian (Wang and Zhou, 2003).

Comments: Know from two specimens, the holotype with a complete, articulated skeleton, and a second disarticulated anterior portion of a skeleton (including a partially disarticulated skull). The postcrania remain undescribed and unillustrated except for the ilium described here. The ilium is long and low, with a relatively straight preacetabular process, a long, tapering postacetabular process that is abruptly truncated distally, and a moderately well developed, triangular brevis shelf. The ischial peduncle is slightly expanded onto the lateral surface. No lateral iliac crest is present.

\section{Lanzhousaurus magnidens You et al., 2005}

Locality: Zhongpu, Lintao County, Gansu Province, People's Republic of China.

Horizon: lower portion of the Hekou Group (possibly equivalent to lower Fengjiashan Formation based on os- tracods).

Age: Barremian (Hayashi 2006)

Comments: A fragmentary specimen lacking the ilium.

\section{Lurdusaurus arenatus Taquet and Russell 1999}

Locality: near Elrhaz, Niger

Horizon: Elrhaz Formation

Age: Aptian (Rauhut and Lopez-Arbarello 2008).

Comments: the postcrania is fragmentary, and no ilium is known.

\section{Mantellisaurus atherfieldensis (Hooley 1925) \\ =Iguanodon atherfieldensis Hooley 1925}

Locality: Atherfield, Isle of Wight, England

Horizon: Vectis Formation

Age: Barremian- lowermost Aptian (Anderson 1967; Martill, personal communication, 2010)

Comments: The considerable differences between Iguanodon bernissartensis and Iguanodon atherfieldensis has long been known (Hooley, 1925; Norman, 1986), although the possibility that these were sexual dimorphs has been suggested (Hooley 1912; Carpenter, 1999). However, as shown by Paul (2006), the differences between the taxa are considerable and warrant separate generic designation. Godefroit et al. (2009: 549) has questioned the splitting of the two taxa into separate genera because no phylogentic analysis was conducted to demonstrate the two species were paraphyletic. However, two closely related genera could show a sister-group relationship, thus making the point of Godefrot et al., irrelevant. The case for separating the two taxa generically had been anticipated by Seeley (1887a: 83): "I therefore find myself differing from M. Dollo, not so much upon he results of his own work, as upon matters in which he depends upon and has the support of one of our most accomplished and most cautious comparative anatomists. 
But when the value of the characteristics of these two Iguanodon types [Iguanodon bernissartensis and Iguanodon mantell], which M. Dollo has so well contrasted, will estimated, I am tempted to ask, is there any living reptilian genus which in the skeletons of its species comprises so wide and varied an assemblage of differential characters? If the differences were limited to one series of characteristics, or to one region of the body, we might accept them as specific; but when they range through all parts of the skeleton, so as to imply many differences in the soft parts of the body, I cannot but reiterate ... my earlier belief that the larger Belgian type constitutes a new genus." Unfortunately, as noted above, the ruling of the ICZN makes it necessary to change the smaller Belgian type as a different genus. If anything Paul (2008) did not go far enough because it is clear that Early Cretaceous iguanodontid genera were far more diverse than generally realized, as shown by Cedar Mountain discoveries, and that the genus Iguanodon is a waste-basket of medium to large ornithopods. How Iguanodon became a waste basket is considered later.

A number of ilia are referred to this taxon (Fig. 2.14a-e) based on their overall similarities in the framework of the variation seen in Camptosaurus ilia (Fig. 4). Variation is seen in the ventral deflection or angle of the preacetabular process, acuteness of the postacetabular process, and prominence of the postacetabular notch. The ilium has a long, slender preacetabular process, short, triangular postacetabular process, short lateral iliac crest, shallow suprailiac notch, wide preacetabular notch, and shallow postacetabular notch. The ischial peduncle is well expanded onto the lateral surface of the ilium.

\section{Muttaburrasaurus langdoni Bartholomai and Molnar 1981}

Locality: Muttaburra, Queensland, Australia

Horizon: Mackunda Formation

Age: Late Albian (Dettmann et al., 2009)

Comments: The ilium has a very sinuous dorsal edge that arcs over the acetabulum then down into a broad suprailiac notch (Fig. 2.15). The preacetabular process is incomplete, but did border a wide preacetabular notch. The lateral iliac crest extends to the distal end of the postacetabular process. The ischial peduncle does not extend onto the lateral surface.

\section{Nanyangosaurus zhugeii Xu et al. 2000}

Locality: People's Republic of China.

Horizon: Sangping Formation, Xiaguan Basin, Neixiang

Age: Albian? (Xu et al. 2000)

Comments: Although the ilium is crushed, is was apparently long and low, with a straight preacetabular proc- ess resulting in an extremely wide preacetabular notch (Fig. 2.16). The postacetabular process is long and distally rounded; there is a prominent postacetabular notch below. The lateral iliac crest is moderately long, but does not extend to the distal end of the postacetabular process. The ischial peduncle is slightly developed on the lateral surface.

\section{Ouranosaurus nigeriensis Taquet 1976.}

Locality: near Elrhaz, Niger

Horizon: Elrhaz Formation

Age: Aptian (Rauhut and Lopez-Arbarello 2008).

Comments: The preacetabular process is extremely long, being half the length of the entire ilium (Fig. 2.17). It is parallel-sided, except near the distal end. It curves slightly ventrally, but still allows for a wide preacetabular notch. The dorsal surface of the ilium forms a gentle arc except for the small suprailiac notch. The postacetabular process is short and triangular. A slight lateral process is developed near the posterior end of the lateral iliac crest. A small postacetabular notch is present.

\section{Penelopognathus weishampeli Godefroit et al 2005}

Locality: Qiriga Village, Nei Mongolia, People's Republic of China.

Horizon: Bayangobi Formation

Age: Aptian (Zhu et al., 2008)

Comments : The ilium is unknown.

\section{Planicoxa depressus (Gilmore 1909) \\ =Camptosaurus depressus Gilmore 1909}

Locality: Buffalo Gap, South Dakota, USA

Horizon: Chilson Member, Lakota Formation.

Age: Valanginian (Sohn, 1979; Dahlstrom and Fox, 1995.

Comments: Originally named Camptosaurus depressus by Gilmore (1909) for the depressed nature of the ilium, it was reassigned to the genus Planicoxa by Carpenter and Wilson (2008). The short, truncated postacetabular process is folded laterally to a horizontal position that is characteristic of the genus (Fig. 2.19). It differs however, from $P$. venenica in straighter dorsal margin, proportionally shorter (less than 50\%) and more robust preacetabular blade relative to ilium length, shallower acetabular notch, and proportionally narrower brevis shelf relative to ilium length. The ischial peduncle is expanded onto the lateral surface.

\section{Planicoxa venenica Dicroce and Carpenter 2001}

Locality: north of Moab, Utah, USA

Horizon: Poison Strip Sandstone, Cedar Mountain Formation 

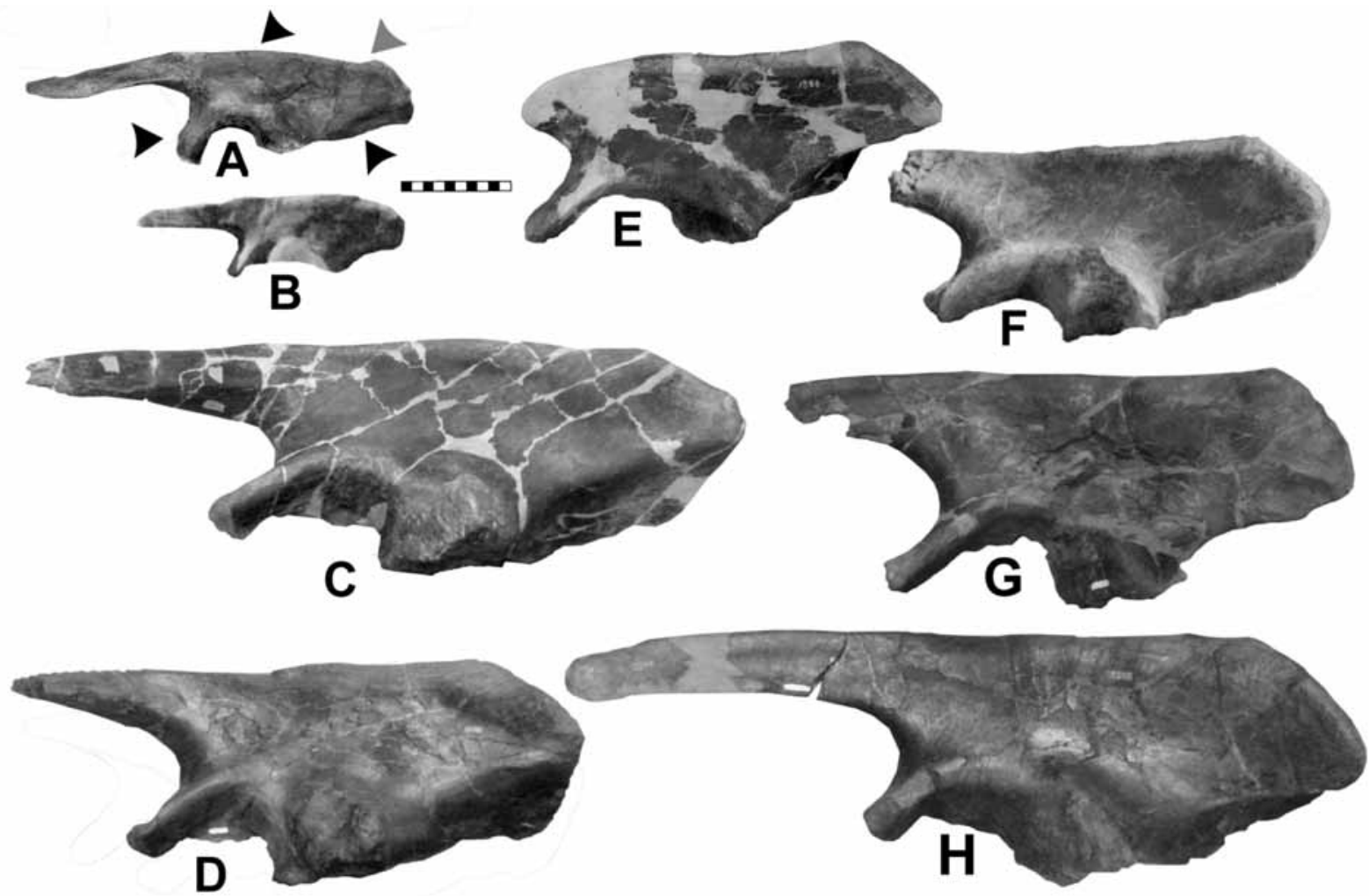

Fig. 4.- Comparison of the ilium in two species of Camptosaurus (black darts point to regions of major differences, grey dart points to a region of uncertain taxonomic value). A, C. aphanoecetes (CM 11337). C. dispar: B, juvenile (USNM 2210 with femur head, holotype of C. nanus): C (USNM 7631 reversed); D (USNM 5818 reversed); E (YPM 1880, holotype of C. medius); F (YPM 1880, holotype of C. medius reversed); G (USNM 5959 reversed); H (USNM 5473 reversed). Scale in cm. E courtesy of Walter Joyce and the Peabody Museum of Natural History. F adapted from Gilmore (1909).

Fig. 4.- Comparación del ilion de dos especies de Camptosaurus (las flechas negras señalan las regiones de mayor diferencia, las grises aquellas regiones con un valor taxonómico poco certero). A, C. aphanoecetes (CM 11337). C. dispar: B, juvenil (USNM 2210 con cabeza de fémur, holotipo de C. nanus): C (USNM 7631 fotografía especular); D (USNM 5818 fotografía especular); E (YPM 1880, holotipo de C. medius); F (YPM 1880, holotipo de C. medius, fotografía especular); G (USNM 5959 fotografía especular); H (USNM 5473 fotografía especular).

Age: Barremian (Zeigler et al. 2007; Ludvigson et al., 2009)

Comments: The ilium (Fig. 2.20)differs from that of $P$. depressus in its more arched dorsal margin, slightly better development of the suprailiac notch, and longer preacetabular process that is half the ilium length. The preacetabular notch is proportionally deeper as well. The ischial peduncle is expanded onto the lateral surface.

\section{Probactrosaurus gobiensis Rozhdestvensky 1966}

Locality: Maortu, Nei Mongol Province, People's Republic of China.

Horizon: Dashuigou Formation

Age: Barremian-Albian (van Itterbeeck et al., 2004).

Comments: Two ilia are shown in Figure 2.21a, b. They show difference in the depth of the preacetabular notch, and slight difference in the ventral angulation of the preacetabular process. The lateral iliac process is a small inverted triangular thickening near the posterior end of the suprailiac crest. A narrow brevis shelf is present along the ventral edge of the large, triangular postacetabular process. The postacetabular notch is small. Laterally, the ischial peduncle is expanded onto the lateral surface of the ilium.

\section{2. "Probactrosaurus" mazongshanensis Lu 1997}

Locality: near Gongpoquan, Gansu Province, People's Republic of China.

Horizon: Middle Grey Unit of Xinminbao Group

Age: Albian (Tang et al., 2001)

Comments: "Probactrosaurus" mazongshanensis is an immature individual as evidenced by the incomplete fusion of the neural arch with the centrum. As noted by Norman (2002), the taxon is distinct from Probactrosaurus gobiensis. We note the following differences: Broad, flat dorsal surface of the parietal in "P." mazongshanensis (narrow sagittal crest in P. gobiensis); large, well developed occipital condyle on a relatively long neck 
Fig. 5.- Holotype pelvis of Proplanicoxa galtoni (BMNH R 8649) in lateral (A), dorsal (B) and posterior $(\mathrm{C})$ views. The ilia show a trend towards the lateral flaring seen in Planicoxa depressus (D - dorsal, F - posterior; USNM 4753) and Planicoxa venenica (E - dorsal, $\mathrm{G}$ - posterior; DMNH 42504). Note the gradational series formed by the three specimens suggesting that they are more closely related to each other than to other iguanodonts. Scale in $\mathrm{cm}$.

Fig. 5.- Pelvis del holotipo de Proplanicoxa galtoni (BMNH $R$ 8649) en vistas lateral (A), dorsal (B) y posterior (C). Los ilion muestran una tendencia hacia la expansión lateral que se observa en Planicoxa depressus (D - dorsal, F - posterior; USNM 4753) y Planicoxa venenica (E - dorsal, $\mathrm{G}$ - posterior; DMNH 42504). Nótese la serie en gradiente que forman los tres especímenes lo que sugiere que están más próximamente relacionados entre sí que con otros iguanodontes. Escala en $\mathrm{cm}$.

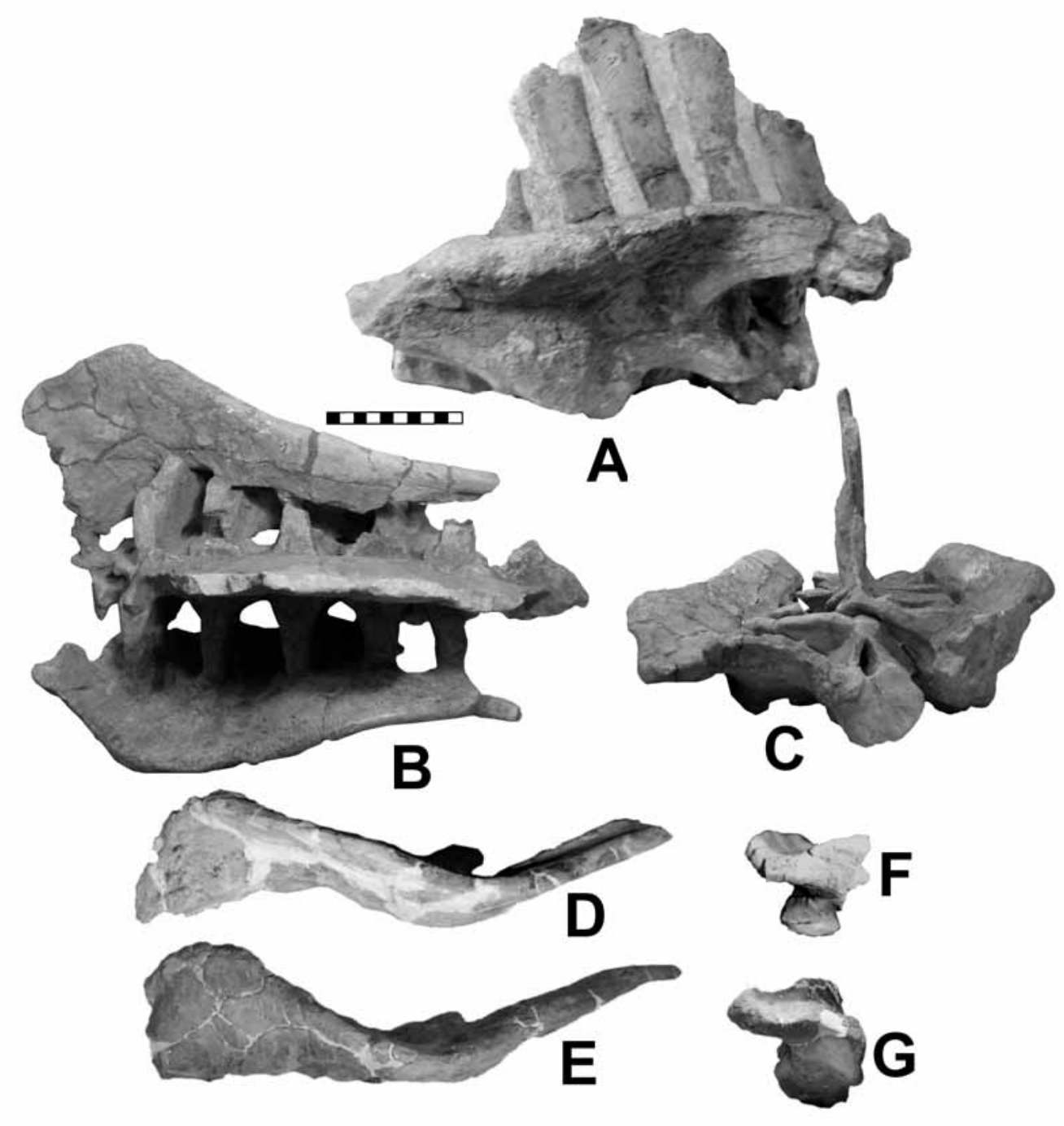

(less prominent condyle lacking a neck in P. gobiensis); straight nuchal crest (embayed, V-shaped nuchal crest in $P$. gobiensis); short, wide supratemporal fenestra in " $P$ " mazongshanensis (long and narrow in P. gobienesis); teeth with large marginal crenulations (small, less developed in $P$. gobiensis); dentary teeth significantly larger than maxillary teeth (nearly same size in P. gobiensis); sacrum rounded ventrally (keeled in $P$. gobiensis); and scapula expanded distally (nearly parallel-sided in $P$. gobiensis).

Equijubus normani and "Probactrosaurus" mazongshanensis were found in the Middle Grey Unit of the Xinminbao Group in the Gongpoquan Basin. The two taxa, however, may be separated by the dentary teeth being larger than the maxillary teeth in "Probactrosaurus" rather than more equal in size in Equijubus (You et al., 2003a), and by the more extensive and prominent marginal crenulations of the teeth of "Probactrosaurus". The teeth of "P." mazongshanensis most closely resemble those of Altirhinus as noted by Norman (2002), however, the scapula is expanded distally more than in Altirhinus. The holotype specimen represents a second iguanodontid in the Gongpoquan Basin and warrants a new generic name.

\section{Protohadros byrdi Head 1998}

Locality: north of Dallas-Fort Worth International Airport, Denton County, Texas, USA.

Horizon: Arlington Member, Woodbine Formation.

Age: Cenomanian (Jacobs and Winkler, 1998).

Comments: no ilium is known.

\section{Proplanicoxa galtoni n.g., n.sp.}

Type Locality: southwest coast of Isle of Wight, England.

Horizon: upper half of the Wessex Formation.

Age: late Barremian (Yans et al., 2005; Dejax et al. 2006; Home, 1995; Martill personal comm., 2010).

Etymology: Pro - Greek for "before" + Planicoxa in reference to the ilium trending towards the horizontal 
postacetabular process seen in Planicoxa. Species honors Peter Galton for his work on European ornithischians.

Holotype: BMNH R 864913 dorsals, sacrum with ilia, parts of pubis and ischium.

Diagnosis: Ilium with short postacetabular process directed dorsolaterally about $50^{\circ}$.

Comments: Galton (1976) referred this specimen to Vectisaurus valdensis Hulke 1879. However, Norman (1990) rightly noted that the syntype material was not diagnostic, a point that Galton now accepts (personal communication, 2009). BMNH R 8649, nevertheless, does have a unique pelvis in which the postacetabular process is short as in Planicoxa and angled subvertically towards the horizontal (Fig. 2.24; 5A-C). This angled condition is not due to crushing as we now know from Planicoxa (Figs. 5D-G). However, in Proplanicoxa the postacetabular process is not horizontal as in Planicoxa venenica (compare Figs. 5C with 5G), but angled dorsolaterally about $50^{\circ}$ above horizontal; Planicoxa compressus is angled about $30^{\circ}$ (Fig. 5F). Thus, the specimens form a gradational series from the plesiomorphic vertical ilium of most iguanodonts to the horizontal ilium of $P$. venenica. The preacetabular process is incomplete, but what remains has parallel dorsal and ventral margins.

\section{Sellacoxa pauli n.g., n.sp.}

Type Locality: Old Roar Quarry, Silverhill, Hastings, East Sussex (see Hopkinson, 1873)

Horizon: lower Wadhurst Clay, Hastings Beds Group (Allen, 1960).

Age: lower Valanginian (Allen and Wimbledon 1991)

Etymology: Genus Sella "saddle" + coxa "hips" (Latin) in reference to the saddle-shaped ilium. Species honors Gregory S. Paul for recognizing that European iguanodon diversity is far greater than formally recognized.

Holotype: BMNH R 3788, includes right ilium, pubis, ischium, and articulated posterior dorsals and sacrals.

Diagnosis: Saddle-shaped ilium with prominent suprailiac notch between prominent dorsal projections near base of preacetabular and postacetabular processes; preacetabular notch narrow, with preacetabular process parallel to pubic penduncle; body of ilium deep; ischial peduncle extends laterally onto main body; pubis deep, dorsal and ventral margins parallel; ischiadic peduncle of pubis massive, extends ventrally; ischium T-shaped, with straight, slender shaft.

Comments: During this survey, we encountered an undescribed, huge partial pelvis identified as Iguanodon dawsoni (Fig. 6). However, the ilium is clearly distinct (see Fig. 2.25) when compared with other ilia (although most superficially resembles that of Tenontosaurus in the shape of the dorsal margin), and represents a new taxon.
The ilium is unlike that of any other iguanodontid, being a tall plate, lacking any suprailiac crest. The pelvis is oriented at $30^{\circ}$ relative to the vertebral column, whereas in all other iguanodontids, the long axis of the ilium is parallel to the vertebrae. However, it is doubtful that this is the normal condition because the pubis, which supports the gut, is placed high and parallel to the vertebrae where this function would be hampered. The steeply angled preacetabular process is unusual in iguanodonts, althought it is also seen in I. bernissartensis.

\section{Shuangmiaosaurus gilmorei You et al., $2003 \mathrm{~b}$}

Locality: Shuangmiao Village, Beipiao County, Liaoning Provence, People's Republic of China.

Horizon: Sunjiawan Formation.

Age: late Albian (Jiang and Sha, 2006; Sha, 2007).

Comments: The ilium is unknown.

\section{Tenontosaurus dossi Winkler et al. 1997}

Locality: near Milsap, Parker County, Texas, USA. Horizon: Twin Mountains Formation.

Age: Aptian (Jacobs and Winkler 1998).

Comment: The ilium (Fig. 27) has the characteristic peculiar postacetabular process that is offset from the rest of the ilium by a prominent suprailiac notch, and by the highly placed triangular lateral iliac process. The dorsal and ventral margins of the preacetabular process are parallel and anteroventrally curved. The ischial process is slightly developed on the lateral side. The ilium of $T$. dossi differs little a from that of T. tilletorum, namely in the proportionally larger, shallower suprailiac notch relative to ilium size, and proportionally smaller (less deep) postacetabular process.

\section{Tenontosaurus tilletorum Ostrom 1970}

Locality: central northern Wyoming - central southern Montana. USA; near Price, Utah?; near Milsap, Parker County, Texas.

Horizon: Himes Member, Cloverly Formation; Mussentuchit Member, Cedar Mountain Formation; Paluxy Formation.

Age: Aptian (Chen and Lubin, 1997; May et al. 1995; Jacobs and Winkler 1998)

Comments: Tenontosaurus tilleti was named "for the Lloyd Tilett family", thus the species-group name must be modified (ICZN 34.3) to "tilletorum" because the "Tilett family" undoubtedly includes both men and women: "if of man (men) and woman (women) together." ICZN 31.1.2.

There are many specimens of ilia, but only three are shown (Fig. 2.28a-c) to represent the variation. In the smallest specimen (Fig. 2.28c), which is about half the 


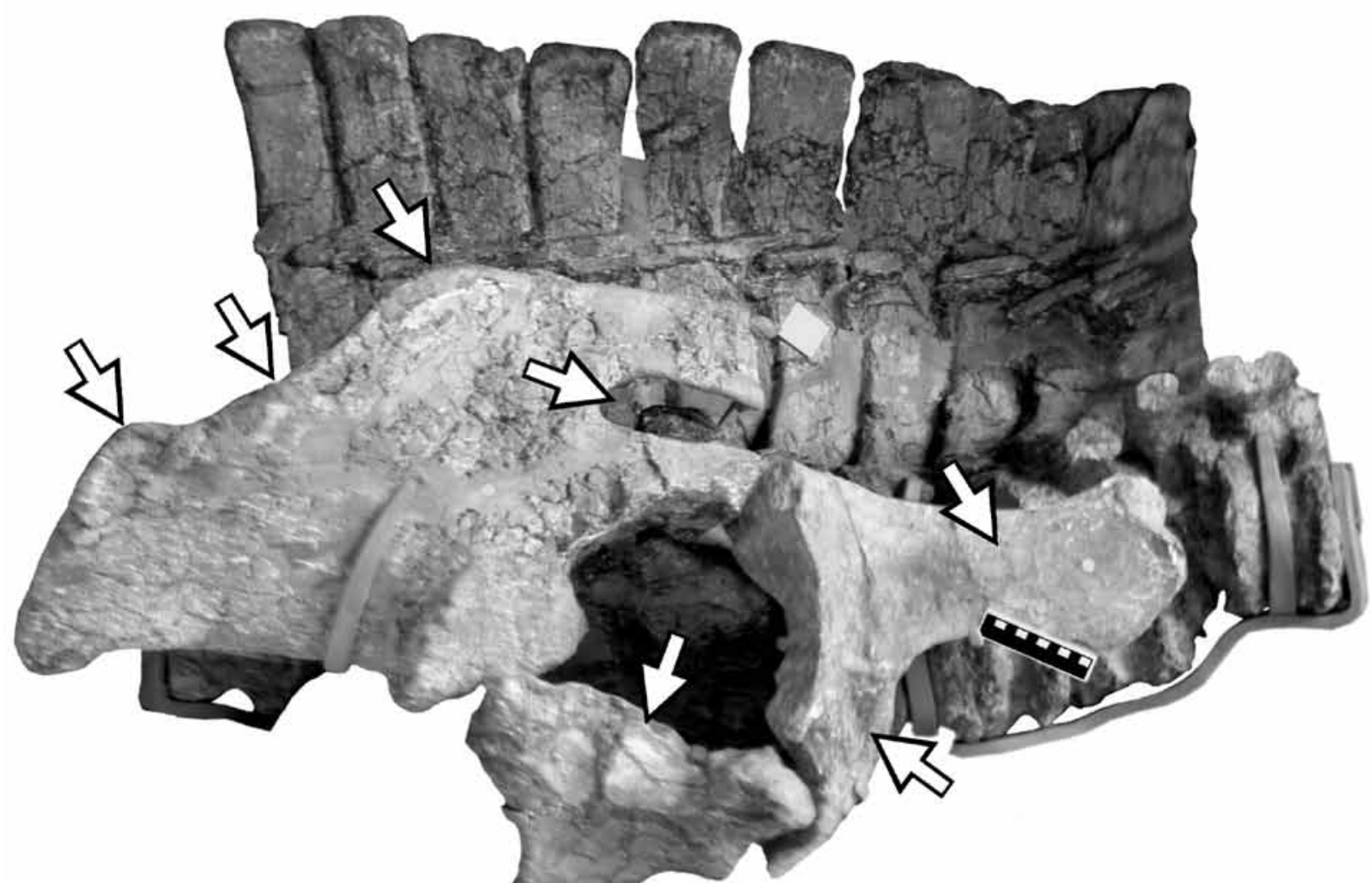

Fig. 6. Holotype of Sellacoxa pauli n.g., n.sp. (BMNH R 3788). Arrows indicate autapomorphies used in the diagnosis. Scale on pubis in $\mathrm{cm}$.

Fig. 6. Holotipo de Sellacoxa pauli n.g., n.sp. (BMNH R 3788). Las flechas señalan las autopomorfías utilizadas en la diagnosis. Escala sobre el pubis en $\mathrm{cm}$.

size of the larger two specimens, the body and the preacetabular notch are shallower and presumably reflect ontogeny. Further variation includes relative depth and length of the suprailiac notch (Fig. 2.28a-c). The brevis shelf is narrow.

\section{Theiophytalia kerri Brill and Carpenter 2006}

Locality: Garden of the Gods, Colorado Springs, Colorado, USA

Horizon: lower part of the Lytle Member, Purgatoire Formation

Age: Aptian-Albian (Mateer, 1987; Tschudy et al., 1984).

Comments: Known only from a skull that was originally referred to Camptosaurus amplus.

\section{Torilion dawsoni n.g. (Lydekker, 1888b) \\ = Iguanodon dawsoni Lydekker, 1888b}

Type Locality: Saint Leonards, East Sussex, England.
Horizon: Wadhurst Clay, Hastings Beds Group (Allen, 1960).

Age: lower Valanginian (Allen and Wimbledon 1991).

Etymology: Torus - Latin for "rounded" and "ilion" Latin for ilium, in reference to the rounded postacetabular process.

Syntypes: BMNH R798, 798a, R803-805 dorsal vertebrae, R806 chevron, R798b dorsal and caudal vertebrae, R802 left ilium and partial pubis, R802a proximal end of tibia, R799-801 metatarsals (Lydekker 1888a: 196-200).

Diagnosis: Ilium deep, slight development of the lateral iliac crest, broad medial shelf on preacetabular process, postacetabular portion long, deep and rounded distally, narrow brevis shelf, shallow postacetabular notch distally located on postacetabular process.

Comments: The holotype ilium (Fig. 2.20) differs significantly from that of Iguanodon bernissartensis as noted by Lydekker (1888b) who acknowledged that it might belong in a new genus. However, as discussed further below, he chose a more conservative approach, but in doing 
so, greatly expanded the concept of the genus Iguanodon. The distinctiveness of the species of Iguanodon also has been noted by Norman (1987) and Blows (1998). Galton (2009), however, had independently of our work concluded that the specimen should not be referred to Iguanodon. Lydekker (1888b) refers to the holotype as consisting of an associated skeleton and lists the bones separately in Lydekker (1888a); these are taken as the type series or collectively as the syntypes (ICZN 73.2).

The preacetabular process is incomplete, but what remains is parallel sided. The ischial peduncle is expanded onto lateral surface.

\section{Wadhurstia fittoni n.g. (Lydekker, 1889a) \\ =Iguanodon fittoni Lydekker, 1889a}

Type Locality: Shornden, East Sussex

Horizon: Wadhurst Clay, Hastings Beds Group (Allen, 1960).

Age: lower Valanginian (Allen and Wimbledon 1991)

Etymology: For the Wadhurst Formation, which produced the holotype.

Holotype: BMNH R 1635a-d left ilium, sacrum, caudal vertebrae, and possibly teeth (Lydekker 1890b: 261).

Diagnosis: Ilium very deep, anteroposteriorly short, lateral surface concave, very wide brevis shelf medially, no medial ridge on preacetabular process, nor lateral iliac crest; suprailiac notch posteriorly placed on the postacetabular process, distal end of process abruptly truncated.

Comments: Originally named Iguanodon fittoni, the holotype ilium differs significantly from that of Iguanodon bernissartensis and warrants its own genus. The distinctiveness of the ilium has been commented upon by Lydekker (1889a; 1890a), who noted similarities with Camptosaurus; Norman (1987) and Blows (1998) also noted it represented a valid species of Iguanodon, but Galton independent of us, also concluded that the specimen should not be referred to that genus.

Although incomplete, the preacetabular process is long and tapering. The ischial peduncle is expanded onto the lateral surface.

\section{Discussion}

Iguanodon has become a wastebasket for Lower Cretaceous medium- to large-sized ornithopods as pointed out by Paul (2006). The historical roots for this tradition can be traced to early work by English paleontologists of the nineteenth century. Key among the specimens available to these paleontologists was the discovery of the Maidstone Iguanodon specimen in 1834 (see above), which proved the benchmark for understanding all subsequent discoveries of ornithopods during the 1800s (which is why it was considered the type of the genus throughout much of the 1800s). The descriptions of the Maidstone Iguanodon by Mantell (e.g. 1835, 1841), but especially that by Owen (1851), provided the defining characters for the genus.

The discovery in 1849 of a small, articulated skeleton minus skull of a small ornithopod from the Isle of Wight was described by Owen (1855) as that of a juvenile Iguanodon. Fox (1869) reported verbally in 1868 of a second specimen with skull from the same locality, and concluded the remains indicated a new, small species of Iguanodon characterized by conical premaxillary teeth. Huxley (1870: 7) restudied both specimens and concluded that "teeth of this reptile leave no doubt as to its distinctness from Iguanodon; ...I propose, therefore, to name it Hypsilophodon Foxii [sic]." He differentiated the two taxa in the shape and proportions of the vertebrae (especially the caudals), femur, and number of metatarsals. Hulke (1873a) added to this list, noting both similarities and differences between Hypsilophodon and Iguanodon. Owen (in Hulke, 1873b, p. 531) disagreed with both Huxley and Hulke claiming the teeth were not that different and that a separate generic name clouded the issue. Hulke (1873b) responded that the similarities indicated a close relationship, but that the number and degree of differences between Iguanodon mantelli and Hypsilophodon foxii in the limbs and vertebrae warranted separation at the genus level. Seeley (in Hulke, 1873b: 23) accepted the distinctiveness of Hypsilophodon, suggesting that differences among the various teeth referred to Iguanodon might in fact belong to different genera. Owen (1874a, b) expanded his position, referring to the specimens as Iguanodon Foxii [sic]. He acknowledged the differences, especially of the teeth, but still felt they indicated specific differences, not generic. Thus, Owen, Huxley, Hulke, and Seeley were faced with a problem that still does not have a satisfactory answer today: How much difference separates species from genera? Hulke (1882b) attempted to resolve the matter of Hypsilophodon once and for all with a detailed description of all the material referable to that taxon and highlighted differences with Iguanodon mantelli.

However, even before this issue of the generic distinctiveness of Hypsilophodon was resolved, another ornithopod skeleton was discovered and referred to Iguanodon as I. prestwichii by Hulke (1880). To make it clear that he considered the new species distinct from I. mantelli he noted some of the differences in the lengthy title. He does note the teeth have "the compressed, ridged, serrate form characteristic of the Family Iguanodontidae" (Hulke 1880: 437). These teeth he notes are simpler than those 
referred to I. mantelli, and furthermore, the shape of the centra differed, as do the numbers and ventral shape of the sacral vertebrae. Owen (in Hulke 1880: 456) "believed the author had established the specific distinctness of the form." However, Seeley (in Hulke 1880: 456) "attach more value than the author had done to the differences of the vertebral column, pelvis, teeth, and limb-bones from those of the ordinary Iguanodon; and he thought they might be generic rather than dependent on age.... he believed that the differences were important enough to justify the author in placing the animal in a new genus." He was even more emphatic a few years later: "More mature consideration has only deepened my conviction that the Iguanodon Prestwichi is not an Iguanodon in the sense in which the term Iguanodon should be used as a generic distinction. There would be an end of zoological method if organic differences of the magnitude which divide this animal from the Iguanodon Mantelli could be classed as specific characters. The earlier writers made species in this way; but it was by the institution of a method altogether distinct from that used in the modern study of existing life. I believe it to be imperative that no such difference of method should prevail in the study of existing and extinct animals, and therefore contend that, since the structures which I have named differentiate the Kimmeridge Clay animal so that it would have been referred to a new genus had it been an existing animal, we have no choice but to class it as a genus, though no name has as yet been proposed to designate its characteristics" (Seeley 1887a: 83). The following year, Seeley (1888b) acted and removed I. prestwichii from Iguanodon and named it Cumnoria prestwichi [sic] (Hulke's original spelling is prestwichii).

Lydekker (1888b: 47) expressed doubts about such a separation, noting "there is much to be said for the view expressed by Prof. Seeley as to its right to generic distinction; but, after having been for some time inclined to adopt this view, I think on the whole that it is better to retain it in the original genus, of which it will form the type of a very distinct group" (what Lydekker meant by group is explained in the next paragraph). The following year he (Lydekker 1889b) was forced to reassess his position while describing the femur of Camptosaurus leedsi. He conceded that I. prestwichii should be separated from Iguanodon, but placed in the genus Camptosaurus Marsh, as C. prestwichii, rather than Cumnoria, where it remains today (Galton and Powell 1980).

The initial hesitancy of Lydekker to accept the generic distinction of $I$. prestwichii explains why he referred a new specimen he had to Iguanodon, as I. dawsoni, despite noting that it "is certainly distinct from both I. Mantelli and $I$. bernissartensis... It was probably more nearly al- lied to the Kimeridgian I. Prestwichi [sic]..." (Lydekker, 1888b: 50). He acknowledges that not everyone agrees with his conservative stance, "In the opinion of many authorities I have little doubt that these differences would be regarded as of generic value, and the question would then arise whether this form should constitute a new genus, or whether it should be classed with I. Prestwicki as a species of Cumnoria, or possibly with $S$. gracilis, as a Sphenospondyllus" (Lydekker, 1888b: 51). Lydekker (1888b) then goes on to establish the groundwork for a broader definition of Iguanodon: "I am, however, inclined to the opinion that it is preferable, at least for the present, to employ the generic term Iguanodon in a sense which will embrace all the variations between the typical and the present form, and I accordingly propose to include the latter in that genus, under the name of Iguanodon Dawsoni. In this sense the genus Iguanodon may be divided into a Euiguanodont group comprising $I$. Mantelli and I. bernissartensis, and characterized by the pointed posterior extremity of the ilium, the short pubis, the twisted ischium, and the compressed sacrals, as well as by certain features of the anterior dorsal vertebrae; and into a Proiguanodont group, including I. Prestwichi and I. Dawsoni, and characterized by the blunt extremity of the ilium, the probably long pubis, the absence of twist in the ischium, and the haemally [i.e., ventrally] flattened sacrum. The Proiguanodont group will be the one connecting the typical forms of the genus with Hypsilophodon and Camptosaurus." It is clear then, that Lydekker was expanding the definition of Iguanodon beyond the accepted concept of what constituted a genus by his contemporaries, and certainly beyond what we would construe today as a biological genus. Lydekker maintained this attitude the following year when he named two new species of Iguanodon, I. fittoni and I. hollingtoniensis, despite noting similarities with Camptosaurus (hence differences from Iguanodon mantelli and I. bernissartensis). Lydekker (1888a) further refined the proiguanodont and euiguanodont groups, giving diagnoses (additional points were added in Lydekker 1890b).

Seeley and Lydekker presented opposite sides of taxonomic philosophy, with Seeley a taxonomic "splitter" in modern parlance and Lydekker a taxonomic "lumper." In their own words, each has said:

Lydekker (1888b: 60)

"I venture to suggest that in the present state of our knowledge the time is past for applying new generic terms, except in those cases where it can be shown with almost complete certainty that the forms to which such terms are applied are distinct from all that have been previously named. It would, indeed, be advantageous if we were beginning de novo to take one particular part of the 


\begin{tabular}{|c|c|c|}
\hline AGE & North America & Europe \\
\hline Cenomanian & \multicolumn{2}{|l|}{$\begin{array}{l}\text { Eolambia caroljonesa } \\
\text { Protohadros byrdi }\end{array}$} \\
\hline \multicolumn{3}{|l|}{ Albian } \\
\hline & $\begin{array}{l}\text { Theiophytalia kerri } \\
\text { Tenontosaurus tillettorum } \\
\text { Tenontosaurus dossi }\end{array}$ & "Iguanodon" mantelli \\
\hline & \multirow{3}{*}{$\begin{array}{l}\text { Planicoxa venenica } \\
\text { Cedrorestes crichtoni }\end{array}$} & \multirow{2}{*}{$\begin{array}{l}\text { Dollodon seelyi } \\
\text { Iguanodon bernissartensis } \\
\text { Mantellisaurus atherfieldensis } \\
\text { Proplanicoxa galtoni }\end{array}$} \\
\hline Barremian & & \\
\hline Hautervivian & & \\
\hline Valanginian & \multirow[t]{2}{*}{$\begin{array}{l}\text { Planicoxa compressus } \\
\text { Dakotodon lakotaensis }\end{array}$} & \multirow[t]{2}{*}{$\begin{array}{l}\text { "Iguanodon" hollingtoniensis } \\
\text { Sellacoxa pauli } \\
\text { Torilion dawsoni } \\
\text { Wadhurstia fittoni }\end{array}$} \\
\hline Berriasian & & \\
\hline
\end{tabular}

Fig. 7.- Distribution of iguanodontids in space and time.

Fig. 7.- Distribución de los iguanodontes en el espacio y en el tiempo.

skeleton, and say that on the evidence of that part, and that part alone, generic terms should be made; but now, even if we could get such a rule assented to and enforced, its application would not be of much value, owing to the heterogeneous materials on which our genera have been founded. Still, even now, something may be done in this direction, if Palaeontologists will but refrain from applying new generic names to specimens belonging to parts of the skeleton totally different from those upon which allied genera have been founded. A specimen, to my mind, is quite as interesting and quite as important if left without a generic name, as it is when made the type of a so-called new genus to which we are unable to assign its proper position in the system, and which, for all we know, may be not separable from a form which has already received one or more names."

Seeley (1883: 60-61):

"These characters clearly differentiate it [Sphenospondylus] from Iguanodon, which is the only genus with which it can be compared, supposing that we take Iguanodon Mantelli as the type... But the genus has since been enlarged to include such types as Iguanodon Prestwichi and I. Seelyi, both of which differ from the type in well-marked and varied characters. What the significance of those differences is may, I fancy, be determined by comparing together existing genera of animals, and noticing the nature of the characters by which they differ. Judged in this way, I think it possible that both these species might be referred to new genera; and from such a point of view I conceive of these vertebrae as indicat-
Altirhinus kurzanovi

Equijubus normani

Nanyangosaurus zhugeii

"Probactrosaurus" mazongshanensis

Shuangmiaosaurus gilmorei

Jinzhousaurus yangi

Penelopognathus weishampeli

Lurdusaurus arenatus Ouranosaurus nigeriensis

Lanzhousaurus magnidens

Probactrosaurus gobiensis

Fukuisaurus tetoriensis

Muttaburrasaurus langdoni

ing a new genus. But if we take the older conception of a genus, which is anatomical and not zoological, and more a matter of paleeontological convenience than a step in evolutionary history, we may rank all these forms

under the one name Iguanodon. It is a matter on which there is likely to be difference of opinion for some time to come. And if I lean towards defining genera so as to make them small, it is because I believe that characters are in this way better appreciated, and because the groups of fossils become better comparable with existing naturalhistory types."

In the end, Lydekker essentially had his way on Iguanodon because of his hugely influential "Catalogue of the fossil Reptilia and Amphibia in the British Museum (Natural History)" (Lydekker 1888a, 1890b). The subsequent catalogue by Woodward and Sherborn (1890) is clearly modeled after Lydekker's versions. Had Seeley written the catalogue, Iguanodon would probably not be the wastebasket it is today.

\section{Conclusion}

Our global examination of Early Cretaceous iguanodonts provides context for descriptions of several new iguanodonts in the Lower Cretaceous Cedar Mountain Formation of central and eastern Utah, USA. The Cedar Mountain Formation spans from the Valanginian lto ower Cenomanian (Kirkland and Madsen 2007; Sames et al., 2008), thus preserves a dinosaurian record as long as the English Lower Cretaceous. The new specimens indicate 
at least two new iguanodonts (possibly three) from the Valanginian-Barremian Yellow Cat Member of the Cedar Mountain Formation, two from the Aptian-Albian Ruby Ranch Member, and one from the Mussentuchit Member. The diversity of the Cedar Mountain iguanodonts is high in context of the English record as currently defined, but is less dramatic if we take the approach advocated by Seeley, namely the generic distinction of many iguanodont species created by Hulke and Lydekker; this approach was used by us above. Because we have found the ilium to be distinct at the generic level, we have proposed several new names for the English material.

This review did not include any of the specimens referred to Iguanodon from continental Europe because of the fragmentary nature of these specimens as noted by Galton (2009) and because the material is assigned to the wastebasket taxon Iguanodon. It will require a substantial analysis of the material, which is outside the scope of this review. We advocate that isolated material no longer be referred to the wastebasket "Iguanodon" because no advantage is conferred over "iguanodont indeterminate" and may in fact obscure diversity.

The distribution of iguanodontids in space and time is summarized in Fig. 7 and on the global maps of Fig. 1. The pre-Valanginian Iguanodon (= Camptosaurus) hoggi is not shown because it is neither Iguanodon nor Camptosaurus (Carpenter and Wilson, 2008), a position also accepted by Paul (2008). Consequently, it has been renamed Owenodon hoggii by Galton (2009).

Based on our review, iguanodonts are present and diverse in both North America and Europe during the Valanginian indicating a significantly earlier origin. They spread into Asia by the Hauterivian probably from Europe across the Turgai Strait. Once in Asia, they underwent a radiation throughout the Early Cretaceous. Iguanodonts appear in the southern hemisphere by the Aptian and appear to have undergone a modest radiation. However, this late arrival and modest radiation probably reflects inadequate sampling of Early Cretaceous beds. The absence of large bodied iguanodonts from Lower Cretaceous of South America has been commented on before, but may reflect inadequate sampling, rather than competitive exclusion with sauropods (Barrett and Upchurch 2005).

\section{Acknowledgments}

We thank the many individuals who have given us access to specimens and provided information: Sandra Chapman and Angela Milner (Natural History Museum, London); John Bird, Don Burge and Reese Barrick (Prehistoric Museum, Price Utah), Yoichi Azuma (Fukui Pre- fectural Dinosaur Museum) and especially to Masatochi Ichijo (HAN Project 21), for access to specimens displayed at the dinosaur expos held in Chiba City, Japan. Finally, a special thanks to David Martill for his support, and to an anonymous reviewer for comments of an earlier version of this manuscript.

\section{References}

Allen, P. (1960): The Hastings Beds Deltas: Recent progress and Easter Field meeting report: 15-18 April 1960. Proceedings of the Geologists' Association, 73: 219-243.

Allen, P., Wimbledon, W.A. (1991): Correlation of NW European Purbeck-Wealden (nonmarine Lower Cretaceous) as seen from the English type-areas. Cretaceous Research, 12: 511-526. http://dx.doi.org/10.1016/0195-6671(91)90005-W

Alonso, A., Floquet, M., Mas, R., Meléndez, A. (1993): Late Cretaceous Carbonate Platforms: Origin and Evolution, Iberian Ranges, Spain. American Association of Petroleum Geologists Memoirs, 56: 297-313.

Anderson, F. W. (1967): Ostracods from the Weald Clay of England. Bulletin of the Geological Survey of Great Britain, 27: 237-69.

Baraboshkin, E.J. (1999): Berriasian-Valanginian (Early Cretaceous) seaways of the Russian Platform Basin and the problem of Boreal/Tethyan correlation. Geologica Carpathica, 50: 1-16.

Baraboshkin, E.Y., Alekseev, A.S., Kopaevich, L.F. (2003): Cretaceous palaeogeography of the North-Eastern Peri-Tethys. $\mathrm{Pa}$ laeogeography, Palaeoclimatology, Palaeoecology, 196: 177208. http://dx.doi.org/10.1016/S0031-0182(03)00318-3

Barrett, P., Upchurch, P.M. (2005): Sauropodomorph diversity through time: Macroevolutionary and paleoecological implications. In: K.A. Curry Rogers, J.A. Wilson (eds.), The sauropods: evolution and paleobiology. University of California Press, Berkeley:125-156.

Bartholomai, A., Molnar, R. E. (1981): Muttaburrasaurus, a new iguanodontid (Ornithischia: Ornithopoda) dinosaur from the Lower Cretaceous of Queensland. Memoirs of the Queensland Museum, 20: 319-349.

Blakey, R. (2009): Paleogeography: http://jan.ucc.nau.edu/ rcb7/ (accessed October 30, 2009).

Blows, W.T. (1998): A review of Lower and Middle Cretaceous dinosaurs of England. In: S.G. Lucas, J.I. Kirkland, J.W. Estep (eds.), Lower and Middle Cretaceous terrestrial ecosystems. New Mexico Museum of Natural History and Science Bulletin, 14: 29-38.

Boulenger, G. A. (1881): Sur l'arc pelvien chez les dinosauriens de Bernissart. Bulletins de L'Académie royale de Belgique, 3eme série 1(5):1-11.

Brill, K., Carpenter K. (2006): A description of a new ornithopod from the Lytle Member of the Purgatoire Formation (Lower Cretaceous) and a reassessment of the skull of Camptosaurus. In: K. Carpenter (ed.), Horns and beaks: ceratopsian and ornithopod dinosaurs. Indiana University Press, Bloomington: 49-67.

British Association for the Advancement of Science (1878): Rules for Zoological Nomenclature. John Murray, London: $27 \mathrm{p}$.

Butler, R. J., Upchurch, P., Norman, D. B. (2008): The phylogeny of the ornithischian dinosaurs. Journal of Systematic Palaeonto- 
logy, 6: 1-40. http://dx.doi.org/10.1017/S1477201907002271

Carpenter, K., (1998): Comments on the proposed designation of Iguanodon bernissartensis Boulenger in Beneden 1881 as the type species of Iguanodon Mantell, 1825, and posed designation of a lectotype. Bulletin of Zoological Nomenclature, 55(3): 240.

Carpenter, K. (1999): Eggs, nests and baby dinosaurs: A look at dinosaur reproduction. Indiana University Press, Bloomington, Indiana: $336 \mathrm{p}$.

Carpenter, K. (2006): Assessing dinosaur faunal turnover in the Cedar Mountain Formation (Lower Cretaceous) of eastern Utah, USA. Ninth International Symposium on Mesozoic terrestrial ecosystems and biota, Abstract and Proceedings Volume: 21-25.

Carpenter, K., Wilson, Y. (2008): A new species of Camptosaurus (Ornithopoda: Dinosauria) from the Morrison Formation (Upper Jurassic) of Dinosaur National Monument, Utah, and a biomechanical analysis of its forelimb: Annals of the Carnegie Museum, 76: 227-264. http://dx.doi.org/10.2992/00974463(2008)76[227:ANSOCO]2.0.CO;2

Carpenter, K., DiCroce, T., Gilpin, D., Kineer, B., Sanders, F., Tidwell, V., Shaw A. (2002): Origins of the Early and "Middle" Cretaceous dinosaurs of North America: implications for plate tectonics. Proceedings of the International Symposium on new concepts in global tectonics. Otero College, La Junta, Colorado: 289-308.

Charig, A., Chapman, S. (1998): Iguanodon Mantell, 1825 (Reptilia, Ornithischia): proposed designation of Iguanodon bernissartensis Boulenger in Beneden, 1881 as the type species, and proposed designation of a lectotype. Bulletin of Zoological Nomenclature 55, 99-104.

Chen, Z.-Q., Lubin, S. (1997): A Fission-Track Study of the Terrigenous Sedimentary Sequences of the Morrison and Cloverly Formations in the Northeastern Bighorn Basin, Wyoming. Mountain Geologist, 34:51-62.

Cifelli, R.L., Kirkland, J.I., Weil, A., Deinos, A.R., Kowallis, B.J. (1997): High-precision ${ }^{40} \mathrm{Ar} /{ }^{39} \mathrm{Ar}$ geochronology and the advent of North America's Late Cretaceous terrestrial fauna: Proceedings National Academy of Science USA, 94: 11163-11167. http://dx.doi.org/10.1073/pnas.94.21.11163

Dahlstrom, D.J. Fox, J.E. (1995): Fluvial architecture of the Lower Cretaceous Lakota Formation, southwestern flank of the Black Hills uplift, South Dakota. United States Geological Survey Bulletin, 1917-S: 1-20.

Dejax, J., Pons, D., Yans, J. (2006): Palynology of the dinosaurbearing Wealden facies in the natural pit of Bernissart (Belgium). Review of Palaeobotany and Palynology, 144: 25-38. http://dx.doi.org/10.1016/j.revpalbo.2005.10.004

Dettmann, M.E., Clifford, H. T., Peters, M. (2009): Lovellea wintonensis gen. et sp. nov. - Early Cretaceous (late Albian), anatomically preserved, angiospermous flowers and fruits from the Winton Formation, western Queensland, Australia. Cretaceous Research, 30: 339-355. http://dx.doi.org/10.1016/j.cretres.2008.07.015

DiCroce, T., Carpenter, K. (2001): New Ornithopod from the Cedar Mountain Formation (Lower Cretaceous) of Eastern Utah. In: D. H. Tanke, K. Carpenter (eds.): Mesozoic vertebrate life. Indiana University Press, Bloomington: 183-196.

Dollo, L. (1882): Premiere note sur les dinosauriens de Bernissart. Bulletin du Musée Royal d'Histoire Naturelle de Belgique, 1:161 - 180 .
Dollo, L. (1888): Iguanodontidae et Camptonotidae. Comptes Rendus de Academie des Sciences, Paris, 106:775-777.

Dollo, L. (1909): The fossil vertebrates of Belgium. Annals of the New York Academy of Sciences, 19: 99-119. http://dx.doi. org/10.1111/j.1749-6632.1909.tb56913.x

Fox, W. (1869): On the skull and bones of Iguanodon. Report of the British Association for the Advancement of Science for 1868: 64-65.

Fujita, M. (2003): Geological age and correlation of the vertebrate-bearing horizons in the Tetori Group. Memoir of the Fukui Prefectural Dinosaur Museum, 2: 3-14.

Galton, P.M. (1976): The dinosaur Vectisaurus valdensis (Ornithischia: Iguanodontidae) from the Lower Cretaceous of England. Journal of Paleontology, 50: 976-984.

Galton, P.M. (2009): Notes on Neocomian (Lower Cretaceous) ornithopod dinosaurs from England - Hypsilophodon, Valdosaurus, "Camptosaurus", "Iguanodon" - and referred specimens from Romania and elsewhere. Revue de Paleobiologie, 28: 211272.

Galton, P.M., Jensen, J.A. (1979): Remains of ornithopod dinosaurs from the Lower Cretaceous of North America. Brigham Young University, Geological Studies, 25(3):1-10.

Galton. P M., Powell, H. P (1980): The ornithischian dinosaur Camptosaurus prestwichii from the Upper Jurassic of England. Palaeontology, 23: 411-443.

Garrison, J.R., Brinkman, D., Nichols, D., Layer, P., Burge, D., Thayn, D. (2007): A multidisciplinary study of the Lower Cretaceous Cedar Mountain Formation, Mussentuchit Wash, Utah: a determination of the paleoenvironment and paleoecology of the Eolambia caroljonesa dinosaur quarry. Cretaceous Research, 28: 461-494.

Gilmore, C.W. (1909): Osteology of the Jurassic reptile Camptosaurus, with a revision of the species of the genus, and descriptions of two new species. United States National Museum Proceedings, 36: 197-332.

Gilpin, D., DiCroce, T., Carpenter, K. (2006): A possible new basal hadrosaur from the Lower Cretaceous Cedar Mountain Formation of eastern Utah. In: K. Carpenter (ed.), Horns and beaks: Ceratopsian and ornithopod dinosaurs. Indiana University Press, Bloomington: 79-89.

Godefroit, P., Li, H., Shang, C.-Y. (2005): A new primitive hadrosauroid dinosaur from the Early Cretaceous of Inner Mongolia (P.R. China). Comptes Rendus Palevol, 4: 697-705. http:// dx.doi.org/10.1016/j.crpv.2005.07.004

Godefroit, P., Codrea, V., Weishampel D. B. (2009): Osteology of Zalmoxes shqiperorum (Dinosauria, Ornithopoda), based on new specimens from the Upper Cretaceous of Nălaț-Vad (Romania). Geodiversita, 31: 525-553.

Hayashi, K. (2006): Nonmarine ostracode zonation and longdistance correlation based on analysis of regional ostracode successions in China, Korea, Japan, and Mongolia. Cretaceous Research, 27: 168-188. http://dx.doi.org/10.1016/j.cretres.2005.11.007

Head, J.J. (1998): A New species of basal hadrosaurid (Dinosauria, Ornithischia) from the Cenomanian of Texas. Journal of Vertebrate Paleontology, 18: 718-738. http://dx.doi.org/10.10 $\underline{\text { 80/02724634.1998.10011101 }}$

Hicks, J.F., Brinkman, D.L., Nichols, D.J., Watabe, M. (1999): Paleomagnetic and palynologic analyses of Albian to Santonian 
strata at Bayan Shireh, Burkhant, and Khuren Dukh, eastern Gobi Desert, Mongolia. Cretaceous Research, 20: 829 - 850. http://dx.doi.org/10.1006/cres.1999.0188

Home, D.J. (1995): A revised ostracod biostratigraphy for the Purbeck-Wealden of England. Cretaceous Research, 16: 639-663.

Hooley, R.W. (1912): On the discovery of remains of Iguanodon mantelli in the Wealden Beds of Brighstone Bay, Isle of Wight. The Geological Magazine, 9: 444-449. http://dx.doi. org/10.1017/S0016756800115705

Hooley, R. W. (1925): On the skeleton of Iguanodon atherfieldensis sp. nov. Quarterly Journal of the Geological Society, 81: 1-60. http://dx.doi.org/10.1144/GSL.JGS.1925.081.01-04.02

Hopkinson, J. (1874): Excursion to Eastbourne and St. Leonards. Proceedings of the Geologists' Association, 3: 211-214.

Hulke, J. W. (1873a): Contribution to the anatomy of Hypsilophodon Foxii. Quarterly Journal of the Geological Society, 29: 522-532. http://dx.doi.org/10.1144/GSL.JGS.1873.029.01$\underline{02.46}$

Hulke J. W. (1873b): Supplemental note on the anatomy of Hypsilophodon Foxii. Quarterly Journal of the Geological Society, 30: 18-23. http://dx.doi.org/10.1144/GSL.JGS.1874.030.01-04.18

Hulke, J.W. (1879): Vectisaurus valdensis, a new Wealden Dinosaur. Quarterly Journal of the Geological Society, 35: 421-424. http://dx.doi.org/10.1144/GSL.JGS.1879.035.01-04.27

Hulke, J. W. (1880): Iguanodon prestwichii, a new species from the Kimmeridge Clay, distinguished from I. mantelli of the Wealden Formation in the S.E. of England and the Isle of Wight by differences in the shape of the vertebral centra, by fewer than five sacral vertebrae, by the simpler character of its tooth-serrature, etc., founded on numerous fossil remains lately discovered at Cumnor, near Oxford. Quarterly Journal of the Geological Society, 36: 433-456. http://dx.doi.org/10.1144/GSL. JGS.1880.036.01-04.36

Hulke, J. W. (1882a): Description of some Iguanodon-remains indicating a new Species, I. Seelyi. Quarterly Journal of the Geological Society, 38: 135-144. http://dx.doi.org/10.1144/GSL. JGS.1882.038.01-04.16

Hulke, J. W. (1882b): An attempt at a complete osteology of Hypsilophodon Foxii, a British Wealden Dinosaur. Proceedings of the Royal Society of London, 33: 1035-1062. http://dx.doi. org/10.1098/rspl.1881.0107

Huxley, T. (1870): On Hypsilophodon Foxii, a new dinosaurian from the Wealden of the Isle of Wight. Quarterly Journal of the Geological Society, 26: 3-12. http://dx.doi.org/10.1144/GSL. JGS.1870.026.01-02.07

ICZN (2000): Opinion 1947. Bulletin of Zoological Nomenclature $57,61$.

Ishida, Y. (2009): A new iguanodontoid skeleton (Dinosauria: Ornithopoda) from the Lower Cretaceous Cedar Mountain Formation of Utah, USA. Unpublished Senior Thesis, Hokkaido University, Sapporo, Japan: 48 p.

Ito, M., Matsukawa, M., Saito, T., Nichols, D.J. (2006): Facies architecture and paleohydrology of a synrift succession in the Early Cretaceous Choyr Basin, southeastern Mongolia. Cretaceous Research, 27: 226 - 240. http://dx.doi.org/10.1016/j. cretres.2005.11.005

Jacobs, L.L., Winkler, D.A. (1998): Mammals, archosaurs, and the Early to Late Cretaceous transition in north-central Texas. In: Y. Tomida, L.J. Flynn, L.L.Jacobs (eds.): Advances in vertebra- te paleontology and geochronology. National Science Museum Monographs, 14: 253-280.

Jiang, B., Sha, J. (2006): Late Mesozoic stratigraphy in western Liaoning, China: a review. Journal of Asian Earth Sciences, 28: 205-217. http://dx.doi.org/10.1016/j.jseaes.2005.07.006

Kirkland, J.I. (1998): A new hadrosaurid from the upper Cedar Mountain Formation (Albian-Cenomanian: Cretaceous) of eastern Utah - the oldest known hadrosaurid (lambeosaurine?). In Lucas, S.G., Kirkland, J.I., Estep, J.W. (eds.): Lower to "Middle" Cretaceous terrestrial ecosystems. New Mexico Museum of Natural History and Science Bulletin, 14: 283-296.

Kirkland, J.I., Madsen, S.K. (2007): The Lower Cretaceous Cedar Mountain Formation, eastern Utah. In: Lund, W.R. (ed.): Field guide to geologic excursions in southern Utah, Geological Society of America, Rocky Mountain Section 2007 Annual Meeting, St. George, Utah. Utah Geological Association Publication, 35: 1-108. http: //utahgeology.org.phtemp.com/UGA_ Pub-35/cd_intro.htm

Kirkland, J., Britt, B., Burge, D., Carpenter, K., Cifelli, R., DeCourten, F., Eaton, J., Hasiotis, S., Lawton, T. (1997): Lower to Middle Cretaceous dinosaur faunas of the Central Colorado Plateau: a key to understanding 35 million years of tectonics, sedimentology, evolution, and biogeography. Brigham Young University Geology Studies, 42:69-103.

Kobayashi, Y., Azuma, Y. (1993): A new iguanodontian (Dinosauria: Ornithopoda) from the Lower Cretaceous Kitadani Formation of Fukui Prefecture, Japan. Journal of Vertebrate Paleontology, 23:166-175. http://dx.doi.org/10.1671/02724634(2003)23[166:ANIDOF]2.0.CO;2

Leidy, J. (1858): Remarks concerning Hadrosaurus. Proceedings of the Academy of Natural Sciences of Philadelphia: 215-218.

Lu J.-C. (1997): A new Iguanodontidae (Probactrosaurus mazongshanensis sp. nov.) from Mazongshan Area, Gansu Province, China. In: Dong Z.-M. (ed.), Sino-Japanese Silk Road Dinosaur Expedition. China Ocean Press, Beijing: 27-47.

Ludvigson, G.A, Gulbranson, E., Rasbury, T., Hunt, G., Stockli, D.F., Joeckel, R. M., González, L. A., Kirkland, J.I., Madsen, S. (2009): Radiometric calibration of the stable isotope chemostratigraphy of the Early Cretaceous Cedar Mountain Formation. Geological Society of America Abstracts with Programs, NorthCentral Section - 43rd Annual Meeting, 41: 7

Lydekker, R. (1888a): Catalogue of the fossil Reptilia and Amphibia in the British Museum (Natural History). Part 1. Containing the orders Ornithosauria, Crocodilla, Dinosauria, Squamata, Rhynchocephalia, and Proterosauria. British Museum (Natural History), London: $309 \mathrm{p}$.

Lydekker, R. (1888b): Note on a new Wealden iguanodont and other dinosaurs. Quarterly Journal of the Geological Society, 44: 46-61. http://dx.doi.org/10.1144/GSL.JGS.1888.044.01$\underline{04.08}$

Lydekker, R. (1889a): Notes on new and other dinosaurian remains. Geological Magazine, Decade III, 6:352-356. http:// dx.doi.org/10.1017/S0016756800176587

Lydekker, R. (1889b): On the remains and affinities of five genera of Mesozoic reptiles. Quarterly Journal of the Geological Society, 45: 41-59. http://dx.doi.org/10.1144/GSL. JGS.1889.045.01-04.04

Lydekker, R. (1890a): Contributions to our knowledge of the dinosaurs of the Wealden and the sauropterygians of the Purbeck 
and Oxford Clay. Quarterly Journal of the Geological Society, 46: 36-53. http://dx.doi.org/10.1144/GSL.JGS.1890.046.01$\underline{04.05}$

Lydekker, R. (1890b): Catalogue of the fossil Reptilia and Amphibia in the British Museum (Natural History). Part 4. Containing the orders Anomodontia, Ecaudata, Caudata, and Labyrinthodontia; and Supplement. British Museum (Natural History), London: $295 \mathrm{p}$.

Mantell, G.A. (1825): Notice on the Iguanodon, a newly discovered fossil reptile, from the sandstone of Tilgate Forest, in Sussex. Philosophical Transactions of the Royal Society of London, 115: 179-186. http://dx.doi.org/10.1098/rspl.1815.0255

Mantell, G. A. (1838): The wonders of geology: Of a familiar exposition of geological phenomena. Relfe and Fletcher, London, $312 \mathrm{p}$.

Mantell, G.A. (1841): Memoir on a portion of the lower jaw of the Iguanodon, and on the remains of the Hylaeosaurus and other saurians, discovered in the strata of Tilgate Forest, in Sussex. Philosophical Transactions of the Royal Society of London, 131: 131-151. http://dx.doi.org/10.1098/rstl.1841.0013

Marsh, O. C. (1881): Principal characters of American Jurassic dinosaurs, Part V. American Journal of Science (Series 3), 21:417423.

Martill, D.M., Naish, D. (2001): Dinosaurs of the Isle of Wight. Field Guides to Fossils Number 10, The Palaeontological Association, London, $464 \mathrm{p}$.

Maruyama, S., Yukio, I., Gaku, K., Masaru, T. (1997): Paleogeographic maps of the Japanese Islands: Plate tectonic synthesis from $750 \mathrm{Ma}$ to the present. The Island Arc, 6: 121-142. http:// dx.doi.org/10.1111/j.1440-1738.1997.tb00043.x

Mateer, N. J. (1987): The Dakota Group of northeastern New Mexico and Southern Colorado. New Mexico Geological Society Guidebook, 38th Field Conference, Northeastern New Mexico: 223-236.

Matsukawa, M., Koarai, K., Shionoya, S., Shinkai, T., Nakada, K., Matsui, T., Aono, H., Kobayashi, N., Okubo, A., Hayashi, K., Ito, M. (2003): Stratigraphy and sedimentary basin developments of the Tetori Group in its main area, central Japan. Journal of the Geological Society of Japan, 109: 383-398.

May, M.T., Furer, L.C., Kvale, E.P., Suttner, L.J., Johnson, G.D., Meyers J.H. (1995): Chronostratigraphy and tectonic significance of the Lower Cretaceous conglomerates in the foreland of central Wyoming. In: S.L. Dorobek, G.M. Ross (eds). Stratigraphic evolution of foreland basins. Society for Sedimentary Geology (SEPM), Special Publication, 52: 97-110. http://dx.doi. org/10.2110/pec.95.52.0097

Nichols, D.J., Matsukawa, M., Ito, M. (2006): Palynology and age of some Cretaceous nonmarine deposits in Mongolia and China. Cretaceous Research, 27: 241-251. http://dx.doi.org/10.1016/j. cretres.2005.11.004

Norman, D.B. (1986): On the anatomy of Iguanodon atherfieldensis (Ornithischia: Ornithopoda). Bulletin Institut Royal des Sciences Naturelle de Belgique, 56, 281-372.

Norman, D.B. (1987): Wealden dinosaur biostratigraphy. In: P. J. Currie, and E. Koster (eds.), Fourth Symposium on Mesozoic terrestrial ecosystems, short papers. Occasional Papers of the Tyrrell Museum of Palaeontology, 3: 161-166.

Norman, D. B., Hilpert, K.-H., Holder, H. (1987): Die Wirbeltierfauna von Nehden (Sauerland), Westdeutschland. Geologie und
Paläontologie in Westphalens, 8:1-77.

Norman, D.B. (1990): A review of Vectisaurus valdensis, with comments on the family Iguanodontidae. In: K. Carpenter, P.J. Currie (eds.): Dinosaur systematics: approaches and perspectives. Cambridge University Press, Cambridge: 147-161.

Norman, D.B. (1993): Gideon Mantell's "mantel-piece": the earliest well-preserved ornithischian dinosaur. In: W.A.S. Sarjeant (ed.): Vertebrate fossils and the evolution of scientific concepts. Modern Geology, 18: 225-145.

Norman D.B. (1998): On Asian ornithopods (Dinosauria: Ornithischia). 3. A new species of iguanodontid dinosaur. Zoological Journal of the Linnean Society, 122: 291-348. http://dx.doi. org/10.1006/zjls.1997.0122

Norman, D. B. (2002): On Asian ornithopods (Dinosauria: Ornithischia). 4. Redescription of Probactrosaurus gobiensis Rozhdestvensky 1966. Zoological Journal of the Linnaean Society, 136:113-144. http://dx.doi.org/10.1046/j.10963642.2002.00027.x

Ostrom, J.H. (1970): Stratigraphy and paleontology of the Cloverly Formation (Lower Cretaceous) of the Bighorn Basin area, Wyoming and Montana. Peabody Museum Natural History Bulletin, 35: 1-234

Owen R. (1851): Fossil Reptilia of the Cretaceous Formations. Part 1. Monograph of the Palaeontographical Society London: 5: 1-118.

Owen, R. (1855): Description of part of the skeleton of a young Iguanodon (Iguanodon Mantelli). Fossil Reptilia of the Wealden Formations. Part 2, Dinosauria. Palaeontological Society Monograph, 7: 1-54.

Owen, R. (1874a): Dinosauria (Iguanodon). Fossil Reptilia of the Wealden and Purbeck Formations. Supplement, 5, Palaeontological Society Monograph, 25: 3-16.

Owen, R. (1874b): Appendix to Supplement No. 5 Monograph on Iguanodon Foxii Ow. Palaeontological Society Monograph: 25: 17-18.

Paul, G. S. (2006): Turning the old into the new: a separate genus for the gracile iguanodont from the Wealden of England. In Carpenter, K. (ed.), Horns and beaks: ceratopsian and ornithopod dinosaurs. Indiana University Press, Bloomington: 69-77.

Paul, G.S. (2008): A revised taxonomy of the iguanodont dinosaur genera and species. Cretaceous Research, 29: 192-216. http:// dx.doi.org/10.1016/j.cretres.2007.04.009

Poole, K.E. (2008): A new specimen of iguanodontian dinosaur from the Cedar Mountain Formation, Grand County, Utah. Unpublished Masters Thesis, Washington University, Saint Louis, Missouri: $55 \mathrm{p}$.

Rauhut, O.W.M., Lopez-Arbarello, A. (2009): Considerations on the age of the Tiouaren Formation (Iullemmeden Basin, Niger, Africa): Implications for Gondwanan Mesozoic terrestrial vertebrate faunas. Palaeogeography, Palaeoclimatology, Palaeoecology, 271: 259-267. http://dx.doi.org/10.1016/j.palaeo.2008.10.019

Rozhdestvensky. A. K. (1966): Novyye iguanodonty iz Tsentral'noy Azii. Filogeneticheskiye v zaimootnosheniya pozdnikh Iguanodontidae i rannikh Hadrosauridae, Palaeontologicheskii Zhurnal, 1966:103-116.

Ruffell, A.H. (1992): Correlation of the Hythe Beds Formation (Lower Greensand Group: early-mid-Aptian), southern England. Proceedings of the Geologists' Association, 103: 273- 
291. http://dx.doi.org/10.1016/S0016-7878(08)80126-5

Sames, B., Schudack, M.E., Cifelli, R.L. (2008): Ostracod evidence for a Berriasian to Valanginian maximum age of some nonmarine formations in the U.S. Western Interior Foreland Basin - Early Cretaceous hiatus likely to be shorter than previously reported. Geological Society of America Abstracts with Programs, 40 (6): 374.

Seeley, H.G. (1883): On the dorsal region of the vertebral column of a new dinosaur (indicating a new genus, Sphenospondylus), from the Wealden of Brook in the Isle of Wight, preserved in the Woodwarbian Museum of the University of Camridge. Quarterly Journal of the Geological Society, 39: 55 - 61. http:// dx.doi.org/10.1144/GSL.JGS.1883.039.01-04.06

Seeley H.G. (1887a): M. Dollo's notes on the dinosaurian fauna of Bernissart. Part. 1. Geological Magazine, Decade 3, 4: 80-87. http://dx.doi.org/10.1017/S0016756800200496

Seeley, H.G. (1887b): M. Dollo's notes on the dinosaurian fauna of Bernissart. Part. 2. Geological Magazine, Decade 3, 4: 124130. http://dx.doi.org/10.1017/S001675680020068X

Seeley, H. G. (1888a): The classification of the Dinosauria. Reports from the British Association for the Advancement of Science, 57th Meeting, Manchester: 698-699.

Seeley, H.G. (1888b): On Cumnoria, an iguanodont founded upon Iguanodon Prestwichi, Hulke. Reports from the British Association for the Advancement of Science, 57th Meeting, Manchester: 698.

Sereno, P. C. (1999): The evolution of dinosaurs. Science, 284: 2137-2147. http://dx.doi.org/10.1126/science.284.5423.2137

Sha, J. (2007): Cretaceous stratigraphy of northeast China: nonmarine and marine correlation. Cretaceous Research, 28: 146170. http://dx.doi.org/10.1016/j.cretres.2006.12.002

Smith, A.G., Smith, D.G., Funnell, B.M. (1994): Atlas of Cenozoic and Mesozoic coastlines. Cambridge University Press, Cambridge: $99 \mathrm{p}$.

Sohn, I.G. (1979): Nonmarine ostracodes in the Lakota Formation (Lower Cretaceous) from South Dakota and Wyoming. United States Geological Survey Professional Paper, 1069: 1-22.

Swinton, W. E. (1951): Gideon Mantell and the Maidstone Iguanodon. Notes and Records of the Royal Society of London, 8: 261-276. http://dx.doi.org/10.1098/rsnr.1951.0020

Tang, F., Luo, Z., Zhou, Z., You, H., Georgi, J.A., Tang, Z., Wang, $X$. (2001): Biostratigraphy and paleoenvironment of the dinosaur-bearing sediments in Lower Cretaceous of Mazongshan area, Gansu Province, China. Cretaceous Research, 22: 115129. http://dx.doi.org/10.1006/cres.2000.0242

Taquet, P. (1976): Géologie et paléontologie du gisement de Gadoufaoua (Aptien du Niger). Cahiers de Paléontologie, Centre National de la Recherche Scientifique, Paris, 191 p.

Taquet, P., Russell, D. A. (1999): A massively-constructed iguanodont from Gadoufaoua, Lower Cretaceous of Niger. Annales du Paleontologie, 85: 85-96. http://dx.doi.org/10.1016/S07533969(99)80009-3

Tschudy, R. H., Tschudy, B. D., Craig, L. C. (1984): Palynological evaluation of Cedar Mountain and Buro Canyon Formations, Colorado Plateau. United States Geological Survey Professional Paper, 1281: 1-24.

Van Itterbeeck, J., Markevich, V.S., Horne, D.J. (2004): The age of the dinosaur-bearing Cretaceous sediments at Dashuiguo, Inner Mongolia, P.R. China based on charophytes, ostracods and paly- nomorphs. Cretaceous Research, 25: 391-409. http://dx.doi. org/10.1016/j.cretres.2004.02.001

von Meyer, J. (1832): Palaeologica zur Geschichte der Erde und ihrer Geschöpfe. Frankfurt am Main, 560 p.

Wang X.L., Xu X, (2002): A new iguanodontid (Jinzhousaurus yangi gen. et sp. nov.) from the Yixian Formation of western Liaoning, China. Chinese Science Bulletin, 46:1669-1672. http://dx.doi.org/10.1007/BF02900633

Wang, X. L., Zhou, Z. H. (2003): Mesozoic Pompei. In: M.M. Chang, P.J. Chen, Y.Q. Wang, Y.Wang (eds.): The Jehol biota. Shanghai Scientific and Technical Publishers: China.19-35. http://dx.doi.org/10.1016/B978-012374173-8.50003-X

Weishampel, D. B., Bjork, P. R. (1989): The first indisputable remains of Iguanodon (Ornithischia: Ornithopoda) from North America: Iguanodon lakotaensis n. sp. Journal of Vertebrate Paleontology, 9: 56-66. http://dx.doi.org/10.1080/02724634.1 $\underline{989.10011738}$

Winkler, D.A., Murry, P.A., Jacobs, L.L. (1997): A new species of Tenontosaurus (Dinosauria: Ornithopoda) from the early Cretaceous of Texas. Journal of Vertebrate Paleontology, 17: 330348. http://dx.doi.org/10.1080/02724634.1997.10010978

Woodward, H. (1885): Iguanodon mantelli Meyer. The Geological Magazine, Decade 3, 2: 10-15. http://dx.doi.org/10.1017/ $\underline{\mathrm{S} 0016756800188211}$

Woodward, A.S., Sherborn, C.D. (1890): A Catalogue of British Fossil Vertebrata. Dulau \& Co., London: 396 p.

Xu X., Zhao X.-J., Lü J.-C., Huang W.-B., Li Z.-Y., Dong Z.M., (2000): A new iguanodontian from Sangping Formation of Neixiang, Henan and its stratigraphical implications. Vertebrata PalAsiatica, 38: 176-191.

Yans, J., Dejax, J., Pons, D., Dupuis, C., Taquet, P. (2005): Implications paléontologiques et géodynamiques de la datation palynologique des sédiments à faciès wealdien de Bernissart (bassin de Mons, Belgique). Comptes Rendus Palevol, 4:135-150. http://dx.doi.org/10.1016/j.crpv.2004.12.003

You, H.-L., Ji, Q., Li, D. (2005): Lanzhousaurus magnidens gen. et sp. nov. from Gansu Province, China: the largest-toothed herbivorous dinosaur in the world. Geological Bulletin of China, 24: 785-794.

You, H.-1., Luo, Z-x., Shubin, N.H., Witmer, L.M., Tang, Z-1., Tang, F. (2003a): The earliest-known duck-billed dinosaur from deposits of late Early Cretaceous age in northwest China and hadrosaur evolution. Cretaceous Research, 24: 347 - 355. http:// dx.doi.org/10.1016/S0195-6671(03)00048-X

You, H.-l., Ji, Q., Li, J., Li, Y. (2003b): A new hadrosauroid dinosaur from the mid-Cretaceous of Liaoning, China. Acta Geologica Sinica, 77: 148-154.

Zeigler, K., Donohoo-hurley, L., Kirkland, J., Geissman, J. (2007): Preliminary paleomagnetic data from the Yellow Cat and Poison Strip Members of the Lower Cretaceous Cedar Mountain Formation (Barremian - Aptian), Green River, Central Utah. Geological Society of America Abstracts with Programs, Rocky Mountain Section - 59th Annual Meeting, 39: 9.

Zhu R., Pan Y., He H., Qin H., Ren S. (2008): Palaeomagnetism and ${ }^{40} \mathrm{Ar} /{ }^{39} \mathrm{Ar}$ age from a Cretaceous volcanic sequence, Inner Mongolia, China: Implications for the field variation during the Cretaceous normal superchron. Physics of the Earth and Planetary Interiors, 169: 59-75. http://dx.doi.org/10.1016/j. pepi.2008.07.025 